\title{
Wild mammals as economic goods and implications for their conservation
}

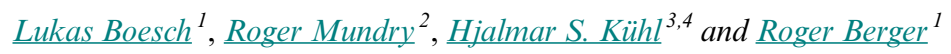

\begin{abstract}
In social-ecological systems, human activities and animal distribution are interrelated. Any effort at studying wildlife abundance therefore requires the integration of detailed socioeconomic context into species distribution models. Wild mammals have always been an important resource for humankind, and concepts of economic goods provide an analytical framework to deduce relevant socioeconomic factors that shape wild mammal-human relationships and consequences for the spatial distribution patterns of wild mammals. We estimated the effects of the human population on wild mammals in a rural area in the Republic of Guinea, West Africa. We related large mammal survey data via statistical models to detailed socioeconomic information about the human population in the same area. We compared models, taking account of the human population in different ways, and found that wild mammal abundance was better explained by human factors other than human population density. Although human population density had a negative effect on wild mammals, the effect of market integration and food taboos were more important and not accounted for by human population density alone. Additionally, the analysis did not provide evidence of higher mammal abundance in classified forests, which one would assume if conservation interventions aimed at reducing hunting were implemented. Beyond doubt, the relationship between humans and wild mammals is highly complex and species- and context-specific. To understand mammal-human relationships in the wider context of social-ecological systems, an in-depth knowledge of the socioeconomic characteristics of a human population is needed to identify crucial links and driving mechanisms.
\end{abstract}

Key Words: economic good; human influence; mammal abundance; Republic of Guinea, West Africa

\section{INTRODUCTION}

Wildlife was "the exclusive source of food, fiber, fuel, and medicine for the first 99\% of human history" (Prescott-Allen and Prescott-Allen 1986:1) and still contributes a significant amount to the welfare of societies, even highly industrialized societies (Prescott-Allen and Prescott-Allen 1986, Chardonnet et al. 2002). It is therefore beyond doubt that wild mammals can be seen as an economic good. Excludability and rivalry are the two fundamental properties of any economic good. Excludability refers to the restriction of access to the good, and rivalry refers to the divisibility of the consumption of the good among individuals (Musgrave and Musgrave 1989). Using these criteria, wild mammals can be classified as common goods in many regions of the world. Common goods are nonexcludable and rivalrous. In contrast to common goods, public goods (e.g., lighthouses, national defense) are nonrivalrous, and private goods (e.g., clothing, food) are excludable. Finally, club goods (e.g., pay TV, gyms) are excludable and nonrivalrous. The properties inherent in common goods may lead to a social dilemma, where appropriators of the common good have the incentive to raise the exploitation of the common good without limit, thereby leading to its destruction. This is because each appropriator receives the whole benefit generated due to an increase in the exploitation of the common good, while the costs that occur due to this increase are divided among all appropriators. This is known as Hardin's "tragedy of the commons": "Freedom in commons brings ruin to all" (Hardin 1968:162). It is important to note that tragedy of the commons situations are characterized by the fact that the appropriators have the option to act differently: they could exploit the resource in a sustainable way, or they even could abstain from exploiting the resource at all and earn their living in other ways (Gardner et al. 1990). Some societies do indeed manage to establish institutional regimes that allow for a sustainable exploitation of a common good. This is achieved by defining clear group boundaries, matching the rules governing the common good to the local conditions and needs, ensuring participation of those affected by the rules, making sure that the rights of affected community members are respected by outside authorities, developing a system where community members monitor other member's behavior, sanctioning rule violators, providing means for dispute resolution, and building responsibility for the governance of the common good on the entire system (Ostrom 1990).

Humans can gain economic value from wild mammals in three ways (Chardonnet et al. 2002). First, nutritious value is gained when humans exploit wild mammals in a direct consumptive way: wild mammals are an important source of meat for humans in many parts of the world, and demand for bushmeat has been identified as one factor that is driving wild mammals to extinction (Davies 2002, Milner-Gulland et al. 2003). Second, productive use value is gained when wild mammals are exploited in a direct nonconsumptive way. Examples for the productive use value of wild mammals are numerous, but trade certainly plays the most important role: wild mammals are an important source of income for humans in many parts of the world (Milner-Gulland et al. 2003), and the trade in wild mammals has been identified as a driver of the extinction of endangered wild mammal species (Madhusudan 2005, Milledge 2007, Nijman and Shepherd 2007, TRAFFIC 2008, Nijman 2010, Briceño-Linares et al. 2011). In the African context, the exploitation of wild mammals includes the whole range, from rural consumption, based on subsistence, to purely commercial activities driven by the demand of international trade (Brashares et al. 2011). Third, even if they do not exploit wild mammals directly, humans can still gain indirect

\footnotetext{
${ }^{1}$ Universität Leipzig, Institut für Soziologie, Leipzig, Germany, ${ }^{2}$ Max Planck Institute for Evolutionary Anthropology, Leipzig, Germany, ${ }^{3}$ Max Planck Institute for Evolutionary Anthropology, Department of Primatology, Leipzig, Germany, ${ }^{4}$ German Centre for Integrative Biodiversity Research (iDiv), Halle-Jena-Leipzig, Leipzig, Germany
} 
nonconsumptive use value from wild mammals. Examples of this value are bird-watching or safari tourism. Finally, wild mammals are an integral part of the ecosystem. Ecosystem functions in turn provide goods and services that are essential for the survival of people. This aspect is not commonly included in the economic value consideration due to the difficulties of quantifying it (De Groot et al. 2002).

The assumption that the property of wild mammals as nonexcludable can be altered has been the foundation for the deer parks in medieval Europe, where the king considered all deer as his private good (Birrell 1992). This assumption is one of the main paradigms of modern conservation policy, which has led to the implementation of strictly protected areas (Gardner et al. 2007), where wild mammals no longer have economic value. The success of protected areas in conserving wild mammal populations is however not guaranteed and depends on substantial efforts (Bruner et al. 2001, Craigie et al. 2010, Tranquilli et al. 2012, 2014), thereby leading to the "mounting realization that protected areas are part of a complex social-ecological system characterized by flux, nonlinear relationships and unpredictable outcomes" (van Wilgen and Biggs 2011:1179). Integrated conservation and development projects therefore assume that the best way to protect wild mammals is to directly involve the local human population: through ownership, economic incentives, and participation, local people should benefit from conservation and support it (Campbell and Vainio-Mattila 2003). This approach is also termed "new conservation" and has been heavily criticized (Soule 2013, Kareiva and Marvier 2014, Marvier 2014).

An understanding of wild mammal-human relationships and the consequences of human activities for the spatial distribution of animals is of major interest for conservation biology and policy because it allows understanding of the relationships between the human population and wild mammals in an area of interest (Elith and Leathwick 2009, Iwamura et al. 2014, Van Vliet et al. 2015). This is an important condition, first, for improving our understanding of social-ecological systems, and second, this understanding is essential for implementing viable conservation programs because the fate of biodiversity and especially wild mammals is closely linked to human behavior and activities (Chazdon et al. 2009, Brncic et al. 2015, Junker et al. 2015). Typically, the set of predictors for modeling species distribution frequently does not include detailed socioeconomic information but only some measure of human population density as a proxy for human activity. Probably this is because spatial information about human population density is easily accessible and does not require the time-consuming collection of detailed spatial socioeconomic context information. However, this approach neglects the fact that some important properties of human populations are not represented by human density. For example, knowing that two areas have the same human population density does not tell us anything about the religious affiliation or the economic activities of the people living in those areas. Not taking account of those differences might lead to biased estimations. Analyzing the relationship between wild mammals and humans within the framework of social-ecological systems can help determine the relevant set of predictors. Ostrom (2007, 2009) proposed a framework where social-ecological systems are made up of four subsystems: the resource system, the resource units, the users, and the governance systems. Although those subsystems are loosely separable, they interact to produce a common outcome at the social-ecological system level. When trying to model the relationship between different factors within a social-ecological system, one should therefore determine the relevant factors from the four subsystems and incorporate them as predictors into the model.

We used a region in the Republic of Guinea as an example to estimate the influence of humans on wild mammal abundance. We compared the predictive value of human population density and other socioeconomic factors on wild mammal abundance. We incorporated the concepts discussed so far into a socialecological system framework, as proposed by Ostrom (2007, 2009), to derive the relevant factors for our model. Finally, we consider how our socioeconomic approach could be used to increase our understanding of wild mammal-human relationships in other regions.

\section{WILD CHIMPANZEE FOUNDATION OFFSET PROJECT IN GUINEA}

The Republic of Guinea (Fig. 1A), located in Western Africa, spans an area of 245,720 $\mathrm{km}^{2}$ (World Bank 2016a). Although its mammal fauna is not well-studied, Guinea is believed to have the highest diversity of large mammals in the West African forests on a species per area basis (Barnett and Prangley 1997). Results from a first nationwide chimpanzee survey, conducted from 1996 to 1997, suggested that Guinea was also home to about 18,000 chimpanzees (95\% confidence limits: 8113-29,011), the largest countrywide population of chimpanzees in West Africa (Ham 1998). A second large-scale chimpanzee survey conducted by the Wild Chimpanzee Foundation (WCF) in 2012 confirmed such a large chimpanzee population (Regnaut and Boesch 2012).

On the other hand, Guinea is one of the poorest and least developed countries in the world. In 2011, Guinea ranked 178 of 187 in the World Development Indicator (UNDP 2016), with a yearly per capita income of US\$447.8 and a life expectancy of 57 years (World Bank 2016b, 2016c). The Guinean economy relies on extractive activities. It has an important mining sector with potential access to one-third of the world's highest grade bauxite deposits, one untouched high-grade iron ore deposit, and gold, diamonds, platinum, cobalt, nickel, silver, uranium, lead, and zinc (Campbell and Clapp 1995). In 2011, Guinea had mineral rents worth $15.8 \%$ of its gross domestic product (GDP) and forest rents worth $13.4 \%$ of its GDP (World Bank 2016d, 2016e). While 35\% of the Guinean population lived in urban areas in 2011 (World Bank 2016f), the rural population relies on ecosystem services for its survival (Laakso and Tyynela 2006) and practices a slash-andburn agriculture. Since "the current level of extraction is low compared to the potential indicated by the resource value on the ground" (World Economic Forum 2011:28), extractive economic activities are believed to further increase. Furthermore, population growth was continuously greater than 2\% from 2004 to 2014 (World Bank 2016g). Past population growth led to a decrease in the fallow period from traditionally 17 years to 8 years (Sirois et al. 1998). Concerns are high that population and economic growth will have a negative effect on the Guinean wild mammal populations if no appropriate measures are taken.

In $2014,15.4 \%$ of the world's terrestrial area was classified as protected area (Juffe-Bignoli et al. 2014). In Guinea, there were 124 resource management and protected areas covering $30 \%$ of 
Fig. 1. (A) Guinea and the broader study region. (B) Transects of the Wild Chimpanzee Foundation biomonitoring project located within a classified forests network in the study region. (C) Study area with the transect segments and the locations of the villages, fields, rivers, roads, and trails.

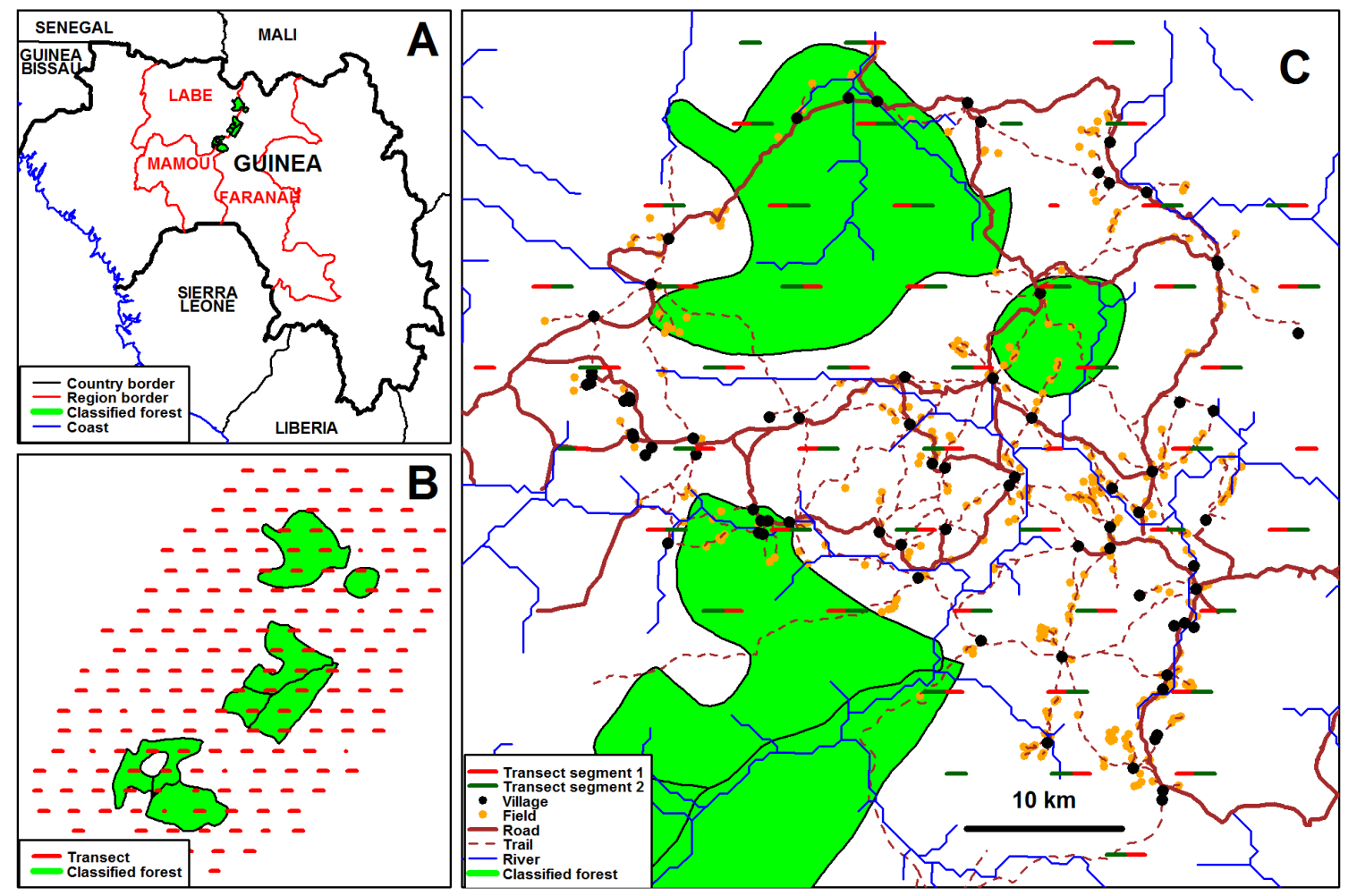

the country's terrestrial area (Protected Planet 2016). Of these, 98 were classified forests (CFs). These are forests that have been classified by the Guinean state as being of national interest. The exploitation of environmental goods in CFs is regulated in a way as to find an equilibrium between the socioeconomic needs of the local population and the interests of conserving the environment (Ministère de l'agriculture et des ressources animales 1999). Only five Guinean protected areas (Kankan Faunal Reserve [IUCN category IV], Mont Nimba Strict Nature Reserve [IUCN category I], Badiar National Park [IUCN category II], Haut Niger National Park [IUCN category II], and Blanche Island Faunal Reserve [IUCN category IV]) were dedicated to the protection of biodiversity. These five protected areas cover $7050 \mathrm{~km}^{2}(2.9 \%)$ of Guinea's terrestrial area, including three of five Guinean ecoregions. Furthermore, not all globally threatened mammals that occur in Guinea are found in these five protected area. These findings highlight the need to increase the number of protected areas that are dedicated to the protection of biodiversity in Guinea (Brugiere and Kormos 2009).

In an effort to create a new national park in the region, the WCF cooperates with the Guinean government, the International Finance Corporation (IFC), and the mining companies Compagnie des Bauxites de Guinée and Global Aluminum Corporation in order to implement a biodiversity offset project in Guinea. The WCF is a nongovernmental organization with the mission "to enhance the survival of the remaining wild chimpanzee populations and their habitat, in West Africa" (WCF 2016). The WCF offset project aims at achieving conservation outcomes from offset programs of the involved mining companies' activities, according to IFC standards (IFC 2012), through the creation of a new national park in Guinea (WCF 2015). The location of this future national park was selected according to abundance data based on the Guinean WCF Chimpanzee Inventory 2012 as well as feasibility criteria (Regnaut and Boesch 2012). The park is located close to the border of Mali, between the Labe-, the Mamou-, and the Faranah regions, and comprises an already existing network of CFs (Fig. 1A).

\section{Study area, sampling, and field data collection}

In 2013 and 2014, data on wild mammals and the human population were collected in the region where the WCF offset project is located to gain a better understanding of the wild mammals, the human population, and human activities in the region. From October 2013 to March 2014, two WCF biomonitoring teams recorded signs and sightings of wild mammals on 184 line transects according to IUCN standards (Kuehl et al. 2008) using a systematic design (systematically segmented track line sampling) and distance sampling methodology (Buckland et al. 2001, Thomas et al. 2010). Transect length was $2.5 \mathrm{~km}$, and spacing between transects was $5.5 \mathrm{~km}$. Total effort was $462.5 \mathrm{~km}$ (185 transects), covering $8153 \mathrm{~km}^{2}$. This was the WCF biomonitoring project area (Fig. 1B). From April 2013 to June 2014, one sociological team, consisting of four 
people and headed by L. B., collected socioeconomic and infrastructure data in the same area. The sociological team focused its effort on a part of the WCF biomonitoring project area. This area is referred to as the study area, and all further details on data and results refer to this study area. The study area comprised 52 transects and 69 villages (Fig. 1C). The transects included in the study area were selected according to the following criteria: they had to be partly located either within a $5-\mathrm{km}$ range of fields or villages, or they had to be within an area surrounded by villages. We conducted long face-to-face interviews with the household heads of the village population and, if necessary and feasible, several other members of the households. The interviews focused on demography, economic practices, and values and beliefs related to the environment (see full questionnaire in Appendix 1). Furthermore, we took GPS track logs of the locations of the villages, their important fields, and the trails and the roads in the study area.

\section{Hypotheses}

Applying the basic concepts briefly described in the Introduction to the situation in the study area enabled us to formulate hypotheses regarding the influence of the local human population on the wild mammals in the study area. Our underlying assumption was that the local population did not gain indirect use value from wild mammals. This assumption was based on our knowledge of the situation on the ground. We considered only the value the local population could deduce by exploiting wild mammals. Furthermore, we did not consider the relevance of wild mammals for other stakeholders or for the ecosystem.

Using the social-ecological system framework proposed by Ostrom (2007, 2009), we defined the situation and the relevant factors the following way. The outcome of interest was wild mammal abundance. The resource units system was made up of mobile wild mammals. The resource system consisted of the habitat where the wild mammals live. We expected the suitability of the habitat for wild mammals to depend on the habitat type (Tews et al. 2004, Guisan and Thuiller 2005), its access to water (Western 1975, Redfern et al. 2003, DeGama-Blanchet and Fedigan 2006, Chammaillé-Jammes et al. 2007), its accessibility (Malcolm and Ray 2000, Develey and Stouffer 2001, Laurence et al. 2006), and its destruction (Tilmann et al. 1994, Pimm and Raven 2000). The user system was made up of the local population living in the study area. We expected the local population to use wild mammals as a source of meat for private consumption (Davies 2002, Milner-Gulland et al. 2003, Brashares et al. 2011) and a source of income (Milner-Gulland et al. 2003, Madhusudan 2005, Milledge 2007, Nijman and Shepherd 2007, TRAFFIC 2008, Nijman 2010, Briceño-Linares et al. 2011, Brashares et al. 2011). The dependency of the local population on wild mammals depends on viable alternatives (Bennett 2002, Milner-Gulland et al. 2003, Brashares et al. 2011, Junker et al. 2015), which are provided through access to the market as well as fishing activities. Whether the population will use wild mammals is further influenced by normative prescriptions about the appropriateness of eating specific kinds of wild animal meat (McDonald 1977, Balée 1985, Pezzuti et al. 2010, Read et al. 2010, Luzar et al. 2012). While the whole population uses wild mammals and can exploit them, a fraction of the population is professional appropriators (hunters) who are specialized in harvesting wild mammals. They depend on the demand of the local population and the access to the market to earn money. The hunters may have special normative prescriptions related to the killing of wild mammal species (McDonald 1977, Balée 1985, Pezzuti et al. 2010, Read et al. 2010), but we assumed that their hunting activities are based essentially on the demand from the local population and the market. The governance system is shaped by the limited influence of the central government, which is restricted to the CFs. Those are under government control, while the rest of the area is divided among the different village communities and is managed by them through customary rules (Table 1).

\section{Analytical methods}

\section{Processing of line transect data}

We aggregated the transect sighting raw data in the following way: first, transects longer than $1600 \mathrm{~m}$ were split into two equally long segments to account for potential local-scale variation in mammal distribution and the predictor variables (although all transects were designed with a length of $2500 \mathrm{~m}$, it was not always feasible to pass through their entire length. This is why the mean length of the "empirical" transects was $2365 \mathrm{~m}$ and nine were shorter than $1600 \mathrm{~m}$ ). Second, sighting types were classified as ephemeral (direct observation and vocalization) or long-lasting (feces, trace, activity, and nest), and were summed up accordingly. Then, per species, we kept only the more common, ephemeral, or longlasting sightings, and finally considered only species with sightings that occurred on at least 10 transect segments (Brncic et al. 2015). This was our proxy for abundance. Finally, we further excluded species for which there was no information about home range sizes available because we needed this information for the habitat type control variable (Table 1, Fig. 2, Table 2).

\section{Determination of predictor variables}

We interviewed 1389 households ( $86 \%$ of all village households) with a total of 10,463 individuals. We recorded the number of individuals living in households and summed all individuals of all households per village to derive village population sizes. Most villages had approximately 230 inhabitants, but there was large variation in population size. In order to assess whether our village population sizes were trustworthy, we also counted the number of buildings in all villages and controlled whether the village population size correlated with the number of buildings in villages. The Pearson correlation between the number of buildings and the population sizes of the villages was 0.97 , which suggested that the population size was indeed trustworthy. We measured the market integration of the village populations by recording monthly shopping trips of individuals and calculating the mean monthly trips to markets of each village population. The mean number of monthly trips to markets of the village populations ranged from 0 to 10.75 . We recorded the number of hunters living in a village and summed them at the village level. Forty-three percent of all households possessed a hunting rifle; $17 \%$ of them hunted regularly. Overall, 15 households had commercial hunters, who hunted nearly every day. The most frequently hunted animals, in decreasing order, were scrub hare, duiker, cane rat, and bushbuck. An average hunter shot 1.56 duikers per month, whereas the best shot 20. Approximately 193 duikers were shot monthly by the people who were interviewed in the study area. We recorded the number of fishers living in a village and summed them at the village level. Eleven percent of all households fished 
Table 1. Predictions, mechanism, variables, and sources of data.

\begin{tabular}{l}
\hline Theoretical mechanism \\
\hline Hypothesis \\
H1) The larger the human population density, the lower wild mammal abunda \\
Wild mammals are an important source of meat for people living in \\
rural areas of economically developing countries (Davies 2002 , \\
Milner-Gulland et al. 2003, Brashares et al. 2011). Humans can use \\
wild mammals as a source of food when they exploit them directly \\
(they may also exploit them for fur, medicine, etc.) (Chardonnet et \\
al. 2002). The people in our study area belong to the category of \\
people living in rural areas of economically developing countries, \\
and we expect the use of wild mammal products for consumption to \\
increase with population density.
\end{tabular}

H2) The higher the market integration, the lower wild mammal abundance. Wild mammals are an important source of income for people living in rural areas of economically developing countries when they have the means to exploit them economically (Davies 2002, MilnerGulland et al. 2003, Brashares et al. 2011). Humans can exploit wild mammals in a direct nonconsumptive way if they are able to sell their products (Chardonnet et al. 2002). The people in our study area belong to the category of people living in rural areas of economically developing countries, and we expect the exploitation of wild mammals for economic purposes by the local population to increase with the market integration of the local population.

H3) The higher the hunting pressure, the lower wild mammal abundance. Hunters are the professional appropriators of wild mammals and are especially dependent on the exploitation of wild mammals for their survival. We expect the exploitation of wild mammals in the study area by hunters to increase with the numbers of hunters active in the study area (Hardin 1968, Gardner et al. 1990).

H4) The higher the supply of the local human population with fish, the higher wild mammal abundance. Fish is an alternative source of animal protein to wild mammals (Milner-Gulland et al. 2003, Junker et al. 2015). We expect the use of wild mammals for food by the local population to decrease with increasing availability of fish.

H5) The higher the number of people abiding to a food taboo targeting a specific wild mammal species, the higher the abundance of this specific wild mammal species.

Food taboos prohibit individuals from obtaining the nutritious value of wild mammals targeted by the taboo. Food taboos reduce the exploitation of species targeted by the taboo (McDonald 1977, Balée 1985, Juarez et al. 2010, Read et al. 2010, Luzar et al. 2012). Food taboos are prevalent in the population of the study area, and we expect species targeted by food taboos to be more abundant than species not targeted by food taboos.

Control

C1) Habitat type

Wild mammals need specific types of habitats to thrive and prosper (Tews et al. 2004, Guisan and Thuiller 2005).

C2) Habitat destruction

The destruction of the habitat influences the distribution of wild mammals (Tilmann et al. 1994, Pimm and Raven 2000). Crop cultivation is the main habitat destruction activity in the study area and should therefore influence wild mammal abundance.

C3) Access to water Wild mammals need access to water to thrive and prosper (Western 1975, Redfern et al. 2003, DeGama-Blanchet and Fedigan 2006, Chammaillé-Jammes et al. 2007)

C4) Protected areas The property rights of land influences the access people have to the resources on the land (Hardin 1968, Musgrave and Musgrave 1989, Gardner et al. 1990, Ostrom 1990). The exploitation of wild mammals should therefore differ between the classified forests (CFs), state owned, and the rest of the area, which is community owned.
Variable and operationalization

Source of data

Market integration:

mean monthly trips to markets of the village population; aggregated at transect segment level $^{\S}$

Population density: number of people living in a village; aggregated at transect segment level ${ }^{\S}$

Socioeconomic survey ${ }^{\dagger \dagger}$; Wild Chimpanzee Foundation (WCF) transect data ${ }^{\dagger}$

Socioeconomic survey ${ }^{\dagger \dagger}$ WCF transect data

Socioeconomic survey $^{\dagger \dagger}$;WCF transect data

Socioeconomic survey ${ }^{\dagger \dagger}$;WCF Fish supply:

number of fishers living in a village; aggregated transect data ${ }^{\dagger}$ at transect segment level ${ }^{\S}$

number of hunters living in a village; aggregated at transect segment level ${ }^{\S}$
Socioeconomic survey ${ }^{\dagger \dagger}$; WCF number of household heads of a village abiding transect data ${ }^{\dagger}$ to a specific food taboo norm; aggregated at transect segment level ${ }^{\S}$

NDVI':

calculated using satellite data of the study area. Vegetation characterizes the structure of the habitat (Tews et al. 2004), and NDVI values correlate with different habitat types (Holben 1986).

Distance to nearest field:

shortest Euclidian distance between transect

segment midpoint and any field

Distance to nearest river:

shortest Euclidian distance between transect segment midpoint and any river

Share classified forests:

proportion of transect segment located inside CFs
RapidEye satellite data ${ }^{\#}$

Track logs from transect data ${ }^{\dagger}$

Spatial hydrology layer; WCF transect data ${ }^{\dagger}$

World database on protected areas $^{\ddagger}$; WCF transect data ${ }^{\dagger}$ socioeconomic survey $^{\dagger \dagger}$; WCF 
C5) Accessibility

The access to wild mammals influences their abundance (Malcolm and Ray 2000, Develey and Stouffer 2001, Laurance et al. 2006).

We expect the access to wild mammals to be easier in proximity to roads.
Distance to nearest road: shortest Euclidian distance between transect segment midpoint and any road
Track logs from socioeconomic survey $^{\dagger \dagger}$; WCF transect data ${ }^{\dagger}$

The transect data are available through the International Union for Conservation of Nature (IUCN) Species Survival Commission A.P.E.S. Database (http:// apesportal.eva.mpg.de/database/archiveTable).

The world database on protected areas is available through the IUCN and the United Nations Environment Project (www.protectedplanet.net).

${ }^{\S}$ See text and Fig. 3 for the process of aggregation.

'The spatial hydrology layer was provided by the WCF. The layer represents the streams in the study area that have water year-round.

"NDVI: Normalized Differenced Vegetation Index

\#Information on the level $3 \mathrm{~A}$ products we used is provided at the following site:

http://web-dev.rapideye.de/rapideye/all-products/ortho.htm

${ }^{\dagger}$ The survey was conducted for this study.

Fig. 2. Pixel Normalized Differenced Vegetation Index (NDVI) values of a landscape surrounding an example transect segment (112_1) and the 11 home range polygons constructed around this transect segment. The shortest distance from the polygon edge to the transect segment (this distance is the same for every location on the edge of the polygon) as well as the mean NDVI values of the pixels located within the home range polygons are shown in parentheses for each species. We obtained home range information from the following sources: duiker: Estes 1991; bushbuck: Estes 1991; African civet: Ayalew et al. 2013; porcupine: Mori et al. 2014; hare: Wildpro 2016; wart hog: Estes 1991; jackal: Estes 1991; common genet: Estes 1991; Guinea baboon: Patzelt 2013; chimpanzee: Estes 1991; patas monkey: Primate Info Net 2016.

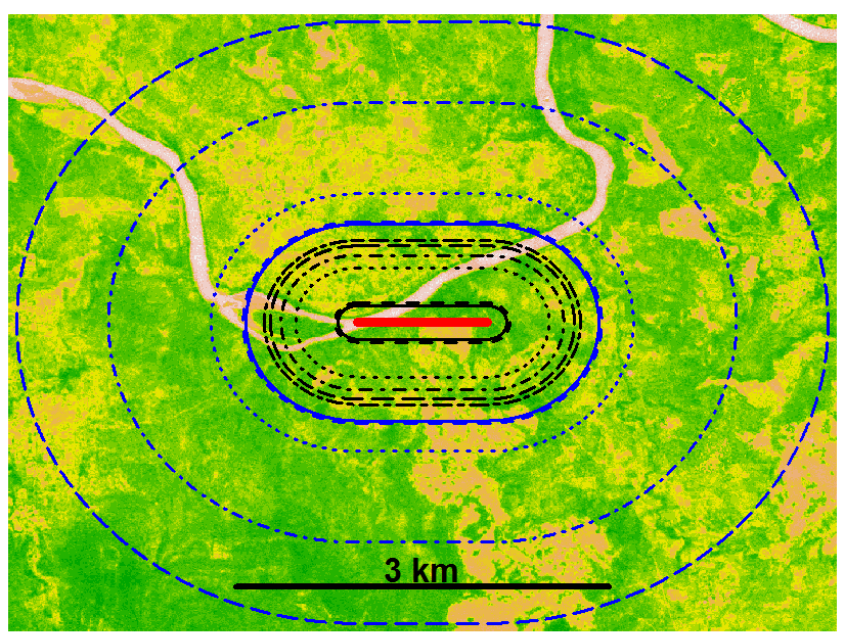

\begin{tabular}{|c|c|c|c|c|}
\hline - & Duiker $(152 \mathrm{~m}, 0.418)$ & 一 & Jackal $(892 \mathrm{~m}, 0.410)$ & NDVI \\
\hline-- & $\begin{array}{l}\text { Bushbuck (178 } \mathrm{m}, 0.414) \\
\text { African civet (493 m, 0.382) }\end{array}$ & -- & $\begin{array}{l}\text { Common genet }(914 \mathrm{~m}, 0.409) \\
\text { Guinea baboon }(1170 \mathrm{~m}, 0.400)\end{array}$ & \\
\hline$\cdots$ & Crested porcupine $(610 \mathrm{~m}, 0.402)$ & $\cdot-\cdot$ & Chimpanzee $(1995 \mathrm{~m}, 0.404) \quad-0.02$ & 0.71 \\
\hline-- & $\begin{array}{l}\text { Scrub hare }(695 \mathrm{~m}, 0.411) \\
\text { Common wart hog }(744 \mathrm{~m}, 0.412)\end{array}$ & - - & Patas monkey (2731 m, 0.411) & Transect segment 112_1 \\
\hline
\end{tabular}

regularly, and 45 households fished nearly every day. For each village, we recorded the number of household heads who abided to food taboo norms that forbid eating certain wild mammal species, and summed them at the village level. The population in the study area was strongly religious, and animistic beliefs survived side-by-side with the Muslim religion. Species targeted with food taboos were chimpanzees, common wart hogs, Guinea baboons, and patas monkeys. Household heads' food taboo abidance ranged from 0 to $100 \%$ per village (Table 1, Table 3 ).

\section{Determination of control variables}

The studied human population practiced slash-and-burn crop cultivation. The most important crops were rice and peanut. Both were cultivated by approximately $95 \%$ of all households during the 2013 growing season. During this season, households harvested an average of $191 \mathrm{~kg}$ of rice, with a maximum of 3 tons, and an average of $602.6 \mathrm{~kg}$ of peanuts, with a maximum of 6 tons. Other important crops were manioc, millet, and beans. Humanwildlife conflicts were very common because wild mammals and humans competed for the crops in the fields. Ninety-five percent of all households were troubled by wild mammals in their fields, and they all took retaliatory measures when wild mammals entered their fields. We took crop cultivation as a proxy for habitat destruction, and computed the shortest Euclidian distance between transect segments' midpoints and any field. Access to water was calculated as the shortest Euclidian distance between transect segments' midpoints and any stream in the study area that had water year-round. Accessibility of the study area was very rudimentary; it was provided by a few dirt roads that were maintained by the local people, and rivers could be crossed only during the dry season (from November to June). We measured the accessibility of the transect segments as the shortest Euclidian distance between transect segments' midpoints and any road. Four CFs were located within the study area. For each transect segment, we determined its proportion that was located within a CF by using the World Database on Protected Areas layer (IUCN and UNEP-WCMC 2016). On 1 and 2 December 2013, 13 RapidEye Level 3A tiles (Rapideye 2016) of the study area were acquired. We used those satellite images to calculate the Normalized Differenced Vegetation Index (NDVI). The NDVI has been successfully used to predict animal population size (Osborne et al. 2001, Oindo et al. 2002, Zinner et al. 2002), and land cover types can consistently be stratified as a function of the NDVI (Holben 1986). We then extracted the mean NDVI within polygons around each transect. The shortest distance from each point on the edge of the polygons to the transect segment was equivalent to the home range radius for each species (Table 1 , Table 3, Fig. 2). 
Table 2. Raw sighting type records, by species and their respective aggregated abundance.

\begin{tabular}{|c|c|c|c|c|c|c|c|}
\hline Species & $\begin{array}{c}\text { Feces } \\
\text { (long-lasting) }\end{array}$ & $\begin{array}{c}\text { Trace } \\
\text { (long- } \\
\text { lasting) }\end{array}$ & $\begin{array}{c}\text { Nest } \\
\text { (long- } \\
\text { lasting) }\end{array}$ & $\begin{array}{l}\text { Observation } \\
\text { (ephemeral) }\end{array}$ & $\begin{array}{l}\text { Activity }{ }^{\dagger} \text { (long- } \\
\text { lasting) }\end{array}$ & $\begin{array}{l}\text { Vocalization } \\
\text { (ephemeral) }\end{array}$ & Abundance \\
\hline $\begin{array}{l}\text { Cane rat } \\
\text { (Thryonomys gregorianus) }\end{array}$ & 9 & 3 & 0 & 0 & 0 & 0 & Species not included \\
\hline $\begin{array}{l}\text { African buffalo } \\
\text { (Syncerus caffer) }\end{array}$ & 10 & 0 & 0 & 0 & 0 & 0 & Species not included \\
\hline $\begin{array}{l}\text { Hippopotamus } \\
\text { (Hippopotamus } \\
\text { amphibius) }\end{array}$ & 1 & 3 & 0 & 0 & 0 & 1 & Species not included \\
\hline $\begin{array}{l}\text { Otter } \\
\text { (Aonyx capensis or } \\
\text { Hydrictis maculicollis) }\end{array}$ & 1 & 0 & 0 & 0 & 0 & 0 & Species not included \\
\hline $\begin{array}{l}\text { Red river hog } \\
\text { (Potamochoerus porcus) }\end{array}$ & 3 & 0 & 0 & 0 & 0 & 0 & Species not included \\
\hline $\begin{array}{l}\text { Green monkey } \\
\text { (Chlorocebus sabaeus) }\end{array}$ & 0 & 0 & 0 & 3 & 0 & 2 & Species not included \\
\hline $\begin{array}{l}\text { Mongoose }^{\ddagger} \\
\text { (Herpestidae) }^{\text {Horpes }}\end{array}$ & 0 & 1 & 0 & 1 & 0 & 0 & Species not included \\
\hline $\begin{array}{l}\text { Common genet } \\
\text { (Genetta genetta) }\end{array}$ & 14 & 0 & 0 & 0 & 0 & 0 & 14 \\
\hline $\begin{array}{l}\text { African civet } \\
\text { (Civettictis civetta) }\end{array}$ & 25 & 0 & 0 & 1 & 0 & 0 & 25 \\
\hline $\begin{array}{l}\text { Bushbuck } \\
\text { (Tragelaphus scriptus) }\end{array}$ & 20 & 8 & 0 & 1 & 0 & 0 & 28 \\
\hline $\begin{array}{l}\text { Duiker } \\
\text { (Cephalophus spp.) }\end{array}$ & 28 & 1 & 0 & 0 & 0 & 0 & 29 \\
\hline $\begin{array}{l}\text { Jackal } \\
\text { (Canis adustus) }\end{array}$ & 32 & 0 & 0 & 1 & 0 & 0 & 32 \\
\hline $\begin{array}{l}\text { Crested porcupine } \\
\text { (Hystrix cristata) }\end{array}$ & 6 & 37 & 0 & 0 & 0 & 0 & 43 \\
\hline $\begin{array}{l}\text { Patas monkey } \\
\text { (Erythrocebus patas) }\end{array}$ & 80 & 0 & 0 & 4 & 0 & 0 & 80 \\
\hline $\begin{array}{l}\text { Scrub hare } \\
\text { (Lepus microtis) }\end{array}$ & 116 & 0 & 0 & 4 & 0 & 0 & 116 \\
\hline $\begin{array}{l}\text { Guinea baboon } \\
\text { (Papio papio) }\end{array}$ & 125 & 104 & 0 & 5 & 0 & 8 & 229 \\
\hline $\begin{array}{l}\text { Common wart hog } \\
\text { (Phacochoerus africanus) }\end{array}$ & 307 & 286 & 0 & 6 & 0 & 0 & 593 \\
\hline $\begin{array}{l}\text { Chimpanzee } \\
\text { (Pan troglodytes) }\end{array}$ & 14 & 0 & 994 & 1 & 35 & 2 & 1043 \\
\hline
\end{tabular}

${ }^{\dagger}$ Long-lasting sign of wild mammals others than feces, traces, or nests, usually resulting from food activities.

Mongooses were not determined to the species or genus level; therefore, only the family name is given here.

Aggregation of predictor variables at transect segment levels All predictor variables were further aggregated at the transect segment level. For this process, we first computed the cost distance between all transect segment midpoints and all villages. The cost distance between two points is the path that links the two points with the least traveling effort. The effort was obtained by considering the slope and the distance between two points. We set the slope to 0 on terrain with a road or a trail, and otherwise set it to the steepness of the terrain. We used the costDistance function of the gdistance package in R (van Etten 2015, R Core Team 2016), a Shuttle Radar Topography Mission digital elevation model (Jarvis et al. 2008), our track logs of all roads, trails and villages, and the locations of the transect segments to compute the cost distance between all transect segments and villages. Our main assumption for the aggregation process, based on our experience in the field and other studies (N'Goran et al. 2012), was to define an activity radius of the local population of up to $25 \mathrm{~km}$. This means that we assumed that villagers living outside the $25-\mathrm{km}$ radius around a transect segment had no influence on wild mammals on the respective transect segment, and that the influence of villagers within the $25-\mathrm{km}$ radius around a transect segment decreased with increasing cost distance to the transect segment. We constructed $25-\mathrm{km}$ activity radii around all transect segment midpoints and selected all villages within the activity radii. The values of the predictor variables within the transect segment activity radii were then weighted with the respective inverse cost distance and then were summed per transect (Table 3, Fig. 3).

\section{Model-building}

First, we identified all species with abundance data that followed approximately a Poisson distribution. This was the case for duiker, bushbuck, African civet, crested porcupine, scrub hare, common wart hog, jackal, common genet, Guinea baboon, and patas monkey. Chimpanzee abundance data, on the other hand, were highly overdispersed with an excess number of zeroes and some very high values. We built two data sets, the mixed species abundance data (938 cases) and the chimpanzee abundance data 
Table 3. Summary statistics of variables.

\begin{tabular}{|c|c|c|c|c|}
\hline Variable & Mean & $\begin{array}{l}\text { Standard } \\
\text { deviation }\end{array}$ & Minimum & Maximum \\
\hline Village: population size & 213 & 174 & 8 & 867 \\
\hline Transect segment: population density & 1667.194 & 720.520 & 354.100 & 3223.866 \\
\hline Village: mean monthly trips to markets & 3 & 2.9 & 0 & 10.7 \\
\hline Transect segment: market integration & 23.395 & 16.225 & 1.081 & 59.346 \\
\hline Village: number of fishers & 2.655 & 3.795 & 0 & 18 \\
\hline Transect segment: fish supply & 21.803 & 13.570 & 1.963 & 55.172 \\
\hline Village: number of hunters & 4.121 & 2.791 & 0 & 11 \\
\hline Transect segment: hunting pressure & 32.597 & 12.650 & 9.005 & 58.884 \\
\hline Village: number of household heads not eating chimpanzees & 11.034 & 10.299 & 0 & 44 \\
\hline Transect segment: taboo influence & 87.019 & 41.023 & 17.530 & 182.621 \\
\hline Village: number of household heads not eating wart hogs & 6.603 & 7.014 & 0 & 26 \\
\hline Transect segment: taboo influence & 52.080 & 24.458 & 10.551 & 113.196 \\
\hline Village: number of household heads not eating Guinea baboons & 6.414 & 7.260 & 0 & 28 \\
\hline Transect segment: taboo influence & 50.209 & 23.429 & 10.332 & 107.537 \\
\hline Village: number of household heads not eating patas monkeys & 6.414 & 7.260 & 0 & 28 \\
\hline Transect segment: taboo influence & 50.209 & 23.429 & 10.332 & 107.537 \\
\hline Transect segment: share classified forest & 0.22 & 0.39 & 0 & 1 \\
\hline Transect segment: distance nearest road $(\mathrm{m})$ & 2742 & 2146 & 6 & 9401 \\
\hline Transect segment: distance nearest river $(\mathrm{m})$ & 1979 & 1299 & 8 & 5020 \\
\hline Transect segment: distance nearest field (m) & 2091 & 1525 & 93 & 6609 \\
\hline Transect segment: Normalized Differenced Vegetation Index & 0.50 & 0.08 & 0.18 & 0.69 \\
\hline
\end{tabular}

Fig. 3. From village population size to transect segment population density. (A) Population size is available only at the village level. The area of the black points shows the village population sizes. (B) Villages were assumed to have an influence on the respective transect segments when they fell within the respective 25-km action radius (red and green circle). (C) The population size figures of the villages that influenced the respective transect segments were weighted with the inverse cost distance to the respective transect segment and summed up, resulting in different population densities on the two transect segments, which are represented by the area of the grey points. (D) The result of the aggregation process of village population size, which resulted in population densities for each transect segment in the study area. We aggregated all predictor variables determined in villages in this way.
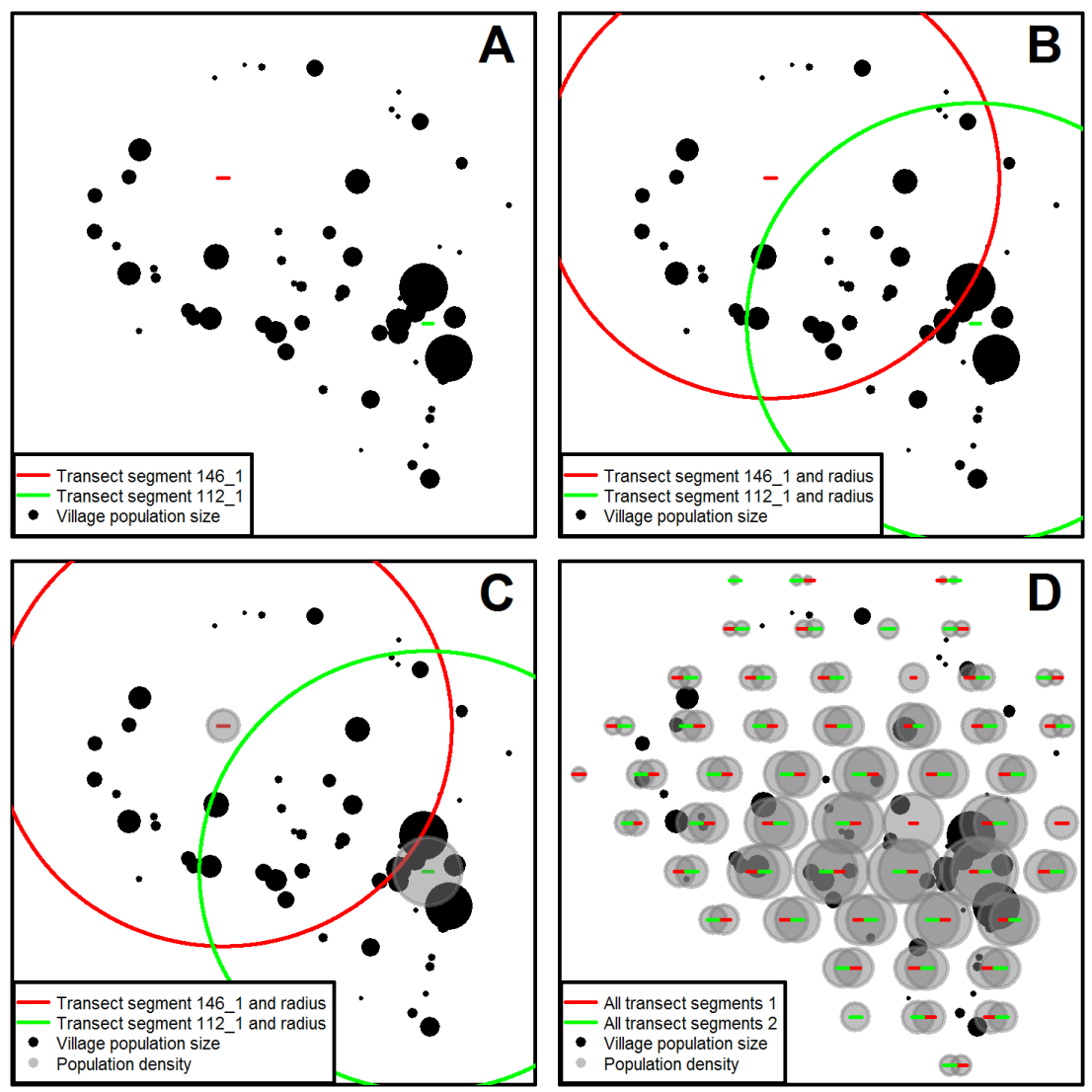
(97 cases). We used mixed effects Poisson regression models to estimate the influence of the human population on the mixed species abundance, and used zero inflated negative binomial regression models to estimate the influence of the human population on chimpanzee abundance (McCullagh and Nelder 1996, Baayen 2008). Because some of the correlations among predictors (population density, market integration, fish supply, hunting pressure, taboo influence) were very high (Table A2.1, A2.2), we were not able to fit models that included all test and control predictors. Instead, we used multimodel inference (Burnham and Anderson 2002). Because the full model with all test and control predictors was characterized by large collinearity (maximum Variance Inflation Factor [VIF] 25.8) (Field 2005), we constructed the set of models in the following way: to begin with, we included a model that comprised the five control predictors only (share classified forests, distance nearest road, distance nearest river, distance nearest field, NDVI) and all models that included all five control predictors and one of the five test predictors (market integration, hunting pressure, fish provision, taboo influence, population density) at a time (six models for the mixed species abundance data and for the chimpanzee abundance data). The model that comprised the control predictors and population density corresponded to a standard ecological model. Since we were specifically interested in the combined effects of taboo influence, market integration, hunting pressure, fish provision, and population density, we added all models that contained combinations of these test predictors and all the control predictors with a maximum $\mathrm{VIF} \leq 5$ (eight additional models for the mixed species abundance data, leading to 14 models, and two additional models for the chimpanzee abundance data, leading to eight models). Since we wanted to know to what extent the control predictors contributed to mammal abundance, we added all the above models but without the control predictors to the set of models (14 additional models for the mixed species abundance data, leading to 28 models, and eight additional models for the chimpanzee abundance data, leading to 16 models). Note that this led to a model that comprised none of the test or control predictors. We controlled for varying transect segment length by including it (log transformed) as an offset term (McCullagh and Nelder 1996) into all models. The final model set for the chimpanzee abundance data comprised 16 models. For all models on the mixed species abundance data, we included an autocorrelation term as well as a random intercept of transect segment ID and random intercept of species (random slopes of the autocorrelation term within species and transect we kept in all models). Finally, we also replicated the entire set of 27 models (all models apart from the model that comprised only the intercept), and this time also included the random slopes of all predictors within species and added these models to the set. We included these models because we were interested in whether species were affected differentially by the predictors, and we wanted to avoid overconfident models (Barr et al. 2013). The final model set for the mixed species abundance data comprised 55 models (see Tables A3.1 and A3.2 for the full set of candidate models).

All test and control predictors were transformed when necessary (i.e., to achieve approximately symmetrical distributions and to avoid influential cases) and then were standardized to a mean of zero and a standard deviation of 1 prior to estimation to achieve easier interpretable estimates (Schielzeth 2010). In order to control for autocorrelation (which was no issue for the chimpanzee abundance data), we first fitted a full model that included all test and control predictors, apart from taboo influence, and extracted the residuals from it. We then, separately for each data point, averaged the residuals of all other data points of the same respective species, whereby we weighted their contribution by their distance to the respective data point. By this we derived an "autocorrelation term" to be included in the full model. The function that determined the weights when averaging the residuals had the shape of a normal distribution with a mean of zero and a standard deviation determined such that the likelihood of the full model with the derived autocorrelation term included was maximized. This approach is similar to what was done in Fürtbauer et al. (2011). The 55 mixed effects Poisson regression models (Table A3.1) on the mixed species abundance data were fitted using the glmer function of the lme4 package in $\mathrm{R}$ (Bates et al. 2015). The 16 zero inflated negative binomial regression models (Table A3.2) on the chimpanzee abundance data were fitted using the zeroinfl function of the pscl package in $\mathrm{R}$ (Jackman 2015). For the zero inflated negative binomial regression models, we always included the same predictor and control predictors into the zero part as in the count part. We estimated VIF using the vif function from the car package in $\mathrm{R}$ (Fox and Weisberg 2011) The dispersion parameters of the mixed effects Poisson regression models ranged between 1.028 and 1.143. The dispersion parameter of the zero inflated negative binomial regression models ranged between 0.781 and 0.891 . All Akaike information criterion (AIC) were calculated with the correction for sample size (AICc) (Burnham and Anderson 2002), and the AIC values for the mixed effects Poisson regression models we additionally corrected for overdispersion (QAICc) (Burnham and Anderson 2002). We centered our inference on delta AIC and the $95 \%$ best model confidence set based on Akaike weights (Burnham and Anderson 2002).

\section{Descriptive results}

Wild mammal species abundance

In total, 2303 sightings of 18 species were recorded in the study area. The most frequently recorded sighting type was chimpanzee nest, with 994 records, and the most frequently recorded species was the chimpanzee, with 1046 records. The least frequently recorded sighting type was vocalization, with 13 records, and the least frequently recorded species was otter, with one record (Table 2).

\section{Results of statistical analysis}

Mixed effects Poisson regression models on species abundance The $95 \%$ best model confidence set of our multimodel inference on mixed species abundance included 17 of 55 models (Table 4). Fifteen of these models included random slopes. This indicates that it is important to account for variation between species in how the predictors influenced their abundance. Sixteen of the models from the confidence set comprised the control predictors. The model that comprised only control predictors was also included in the confidence set: with a delta AIC of 9.094 and an Akaike weight of 0.004 , the support for this model was however meager. The fact that most models in the confidence set included the control predictors is strong support for the importance of environmental factors to wild mammal abundance. 
Table 4. Result of multimodel inference on mixed effects Poisson regression on mixed species abundance (duiker, bushbuck, African civet, porcupine, hare, wart hog, jackal, common genet, Guinea baboon, and patas monkey) (AIC: Akaike information criterion; VIF: Variance Inflation Factor).

\begin{tabular}{|c|c|c|c|c|c|c|c|}
\hline Model & $\begin{array}{c}\text { Model } \\
\text { rank }\end{array}$ & $\begin{array}{c}\text { Confidence } \\
\text { set }\end{array}$ & Cum & $\mathrm{AIC}$ & $\begin{array}{l}\text { Akaike } \\
\text { weight }\end{array}$ & $\begin{array}{c}\text { Delta } \\
\text { AIC }\end{array}$ & $\begin{array}{l}\text { Max. } \\
\text { VIF }\end{array}$ \\
\hline Hunting pressure+ Market integration + Taboo influence + control+RS & 1 & yes & 0.372 & 3790.108 & 0.372 & 0.000 & 3.645 \\
\hline Market integration+Taboo influence + Population density + control+RS & 2 & yes & 0.596 & 3791.123 & 0.224 & 1.016 & 5.603 \\
\hline Market integration+Taboo influence+ control+RS & 3 & yes & 0.759 & 3791.753 & 0.163 & 1.645 & 1.972 \\
\hline Hunting pressure+ Market integration + control+RS & 4 & yes & 0.802 & 3794.458 & 0.042 & 4.350 & 3.622 \\
\hline Market integration + control+RS & 5 & yes & 0.843 & 3794.489 & 0.042 & 4.382 & 1.972 \\
\hline Market integration+Population density + control+RS & 6 & yes & 0.884 & 3794.518 & 0.041 & 4.410 & 5.579 \\
\hline Taboo influence+Population pressure+control+RS & 7 & yes & 0.899 & 3796.566 & 0.015 & 6.458 & 1.916 \\
\hline Population density+control+RS & 8 & yes & 0.909 & 3797.349 & 0.010 & 7.242 & 1.916 \\
\hline Hunting pressure + Market integration + Taboo influence+RS & 9 & yes & 0.916 & 3798.063 & 0.007 & 7.955 & 2.897 \\
\hline Fish supply+Taboo influence+ control+RS & 10 & yes & 0.922 & 3798.366 & 0.006 & 8.258 & 1.935 \\
\hline Fish supply+control+RS & 11 & yes & 0.928 & 3798.398 & 0.006 & 8.290 & 1.935 \\
\hline Hunting pressure+control+RS & 12 & yes & 0.932 & 3799.162 & 0.004 & 9.054 & 1.961 \\
\hline Control+RS & 13 & yes & 0.936 & 3799.202 & 0.004 & 9.094 & 1.609 \\
\hline Hunting pressure + control & 14 & yes & 0.939 & 3799.315 & 0.004 & 9.207 & 1.961 \\
\hline Hunting pressure + Market integration + control & 15 & yes & 0.943 & 3799.326 & 0.004 & 9.218 & 3.622 \\
\hline Taboo influence+control+RS & 16 & yes & 0.947 & 3799.330 & 0.004 & 9.223 & 1.629 \\
\hline Hunting pressure + Taboo influence + control $+\mathrm{RS}$ & 17 & yes & 0.951 & 3799.332 & 0.004 & 9.224 & 1.962 \\
\hline Hunting pressure+Taboo influence+ control & 18 & no & 0.954 & 3799.367 & 0.004 & 9.259 & 1.962 \\
\hline Population density+Control & 19 & no & 0.958 & 3799.370 & 0.004 & 9.263 & 1.916 \\
\hline Market integration + Population density+ control & 20 & no & 0.961 & 3799.381 & 0.004 & 9.273 & 5.579 \\
\hline Hunting pressure + Market integration + Taboo influence + control & 21 & no & 0.965 & 3799.389 & 0.004 & 9.282 & 3.645 \\
\hline Taboo influence+Population pressure + control & 22 & no & 0.968 & 3799.430 & 0.004 & 9.322 & 1.916 \\
\hline Market integration + Taboo influence + Population density + control & 23 & no & 0.972 & 3799.447 & 0.003 & 9.339 & 5.603 \\
\hline Fish supply+Taboo influence+control & 24 & no & 0.975 & 3799.461 & 0.003 & 9.353 & 1.935 \\
\hline control & 25 & no & 0.979 & 3799.467 & 0.003 & 9.360 & 1.609 \\
\hline Market integration + control & 26 & no & 0.982 & 3799.468 & 0.003 & 9.360 & 1.972 \\
\hline Taboo influence + control & 27 & no & 0.986 & 3799.489 & 0.003 & 9.381 & 1.629 \\
\hline Fish supply+control & 28 & no & 0.989 & 3799.509 & 0.003 & 9.401 & 1.935 \\
\hline Market integration+Taboo influence+ control & 29 & no & 0.992 & 3799.525 & 0.003 & 9.417 & 1.972 \\
\hline Market integration+Taboo influence+ Population density+RS & 30 & no & 0.995 & 3800.208 & 0.002 & 10.101 & 4.174 \\
\hline Hunting pressure+ Market integration+RS & 31 & no & 0.996 & 3801.730 & 0.001 & 11.623 & 2.874 \\
\hline Market integration+ Taboo influence+RS & 32 & no & 0.997 & 3801.973 & 0.001 & 11.865 & 1.067 \\
\hline Market integration + Population density $+\mathrm{RS}$ & 33 & no & 0.998 & 3802.451 & 0.001 & 12.344 & 4.15 \\
\hline Market integration $+\mathrm{RS}$ & 34 & no & 0.998 & 3803.252 & 0.001 & 13.145 & \\
\hline Taboo influence+Population pressure + RS & 35 & no & 0.998 & 3804.944 & $<0.001$ & 14.836 & 1.065 \\
\hline Population density+RS & 36 & no & 0.999 & 3805.327 & $<0.001$ & 15.219 & \\
\hline Hunting pressure+ Market integration & 37 & no & 0.999 & 3806.384 & $<0.001$ & 16.277 & 2.874 \\
\hline Hunting pressure + Market integration + Taboo influence & 38 & no & 0.999 & 3806.428 & $<0.001$ & 16.320 & 2.897 \\
\hline Hunting pressure & 39 & no & 0.999 & 3806.468 & $<0.001$ & 16.361 & \\
\hline Hunting pressure + Taboo influence & 40 & no & 0.999 & 3806.450 & $<0.001$ & 16.392 & 1.065 \\
\hline Hunting pressure $+\mathrm{RS}$ & 41 & no & 0.999 & 3806.507 & $<0.001$ & 16.400 & \\
\hline Hunting pressure+ Taboo+RS & 42 & no & 0.999 & 3806.591 & $<0.001$ & 16.483 & 1.065 \\
\hline Market integration+ Population density & 43 & no & 0.999 & 3807.053 & $<0.001$ & 16.945 & 4.15 \\
\hline Market integration+Taboo influence+ Population density & 44 & no & 0.999 & 3807.077 & $<0.001$ & 16.969 & 4.174 \\
\hline Population density & 45 & no & 1 & 3807.096 & $<0.001$ & 16.988 & \\
\hline Taboo influence+Population pressure & 46 & no & 1 & 3807.129 & $<0.001$ & 17.021 & 1.065 \\
\hline Fish supply+RS & 47 & no & 1 & 3807.510 & $<0.001$ & 17.402 & \\
\hline Fish supply+Taboo influence+RS & 48 & no & 1 & 3807.523 & $<0.001$ & 17.415 & 1.073 \\
\hline Market integration + Taboo influence & 49 & no & 1 & 3807.924 & $<0.001$ & 17.816 & 1.067 \\
\hline Market integration & 50 & no & 1 & 3807.989 & $<0.001$ & 17.881 & \\
\hline Fish supply+Taboo influence & 51 & no & 1 & 3808.214 & $<0.001$ & 18.106 & 1.073 \\
\hline Fish supply & 52 & no & 1 & 3808.353 & $<0.001$ & 18.245 & \\
\hline Taboo influence & 53 & no & 1 & 3808.434 & $<0.001$ & 18.326 & \\
\hline Taboo influence $+\mathrm{RS}$ & 54 & no & 1 & 3808.473 & $<0.001$ & 18.365 & \\
\hline Intercept only & 55 & no & 1 & 3809.319 & $<0.001$ & 19.210 & \\
\hline
\end{tabular}

Control predictors are share classified forests, distance nearest road, distance nearest river, distance nearest field, and Normalized Differenced Vegetation Index.

RS indicates that random slopes of all predictors within species were included in the model. 
Table 5. Result of the best model (mixed effects Poisson regression) on wild mammal abundance with market, hunting, and taboo influence, and the control predictors (NDVI: Normalized Differenced Vegetation Index).

\begin{tabular}{|c|c|c|c|c|}
\hline \multicolumn{5}{|l|}{ Observations } \\
\hline \multicolumn{5}{|l|}{938 abundance values } \\
\hline Random effects & $N$ & Standard deviation & $x^{2}$ & $P$ value \\
\hline Species intercept & 10 & 0.839 & & \\
\hline Transect intercept & 98 & 0.507 & & \\
\hline Species: Market integration & & 0.253 & 10.656 & 0.001 \\
\hline Species: Taboos ${ }^{\dagger}$ & & 0.079 & 0.048 & 0.826 \\
\hline Species: Hunting pressure & & 0.000 & 0.000 & 1.000 \\
\hline Species: NDVI ${ }^{\dagger}$ & & 0.136 & 0.466 & 0.495 \\
\hline Species: Distance next field ${ }^{\star}$ & & 0.000 & 0.000 & 1.000 \\
\hline Species: Distance next river ${ }^{*}$ & & 0.000 & 0.000 & 1.000 \\
\hline Species: Distance next road ${ }^{+}$ & & 0.100 & 0.521 & 0.471 \\
\hline \multirow{2}{*}{$\begin{array}{l}\text { Species: Share classified forest } \\
\text { Fixed effects }\end{array}$} & & 0.000 & 0.000 & 1.000 \\
\hline & & Estimate & Standard error & $P$ value \\
\hline Intercept & & -7.879 & 0.278 & $<0.001$ \\
\hline Market integration ${ }^{*}$ & & 0.023 & 0.151 & 0.878 \\
\hline Taboo influence $^{\dagger}$ & & 0.406 & 0.197 & 0.039 \\
\hline Hunting pressure ${ }^{\star}$ & & -0.203 & 0.137 & 0.140 \\
\hline $\mathrm{NDVI}^{\dagger}$ & & 0.073 & 0.081 & 0.365 \\
\hline Distance next field ${ }^{*}$ & & 0.214 & 0.087 & 0.014 \\
\hline Distance next river ${ }^{\star}$ & & -0.013 & 0.068 & 0.852 \\
\hline Distance next road ${ }^{\ddagger}$ & & -0.027 & 0.092 & 0.765 \\
\hline Share classified forest ${ }^{\dagger}$ & & -0.065 & 0.072 & 0.368 \\
\hline
\end{tabular}

The best model had an Akaike weight of 0.372 and included hunting pressure, market integration, taboo influence, and the control predictors (Table 5). In this model, the influence of the market integration varied between the species, having a negative effect on duiker, patas monkey, common genet, and common wart hog abundance, a positive effect on jackal, African civet, crested porcupine, and scrub hare abundance, and no clear influence on Guinea baboon or bushbuck abundance (Fig. 4). The model that included population density and the control predictors was also in the confidence set but ranked only eight and had a delta AIC of 7.242 with an Akaike weight of 0.01 (Table 6). The model averaged coefficients revealed that, across all models, taboo influence and distance to the nearest field had by far the strongest influence on species abundance. The stronger the taboo influence and the larger the distance to the nearest field, the larger the wild mammal species abundance. While the NDVI also had a positive influence on species abundance, the share classified forests, the population density, the hunting pressure, and the distance to the nearest river and road had a negative influence on wild mammal abundance. The influences of fish supply and market integration were very close to zero (Fig. 5).

\section{Zero inflated negative binomial regression models on chimpanzee abundance}

The $95 \%$ best model confidence set of our multimodel inference on chimpanzee abundance included seven of 16 models (Table 7). None of these models comprised control predictors, which suggests that environmental factors were not of primary importance in predicting chimpanzee abundance. The best model had an Akaike weight of 0.414 and was the model that included only market integration. The model that included population density alone was also in the confidence set. It had a delta AIC of 2.57 and an Akaike weight of 0.114. The model averaged coefficients of the count part of the zero inflated negative binomial models on chimpanzee abundance showed that while market integration clearly had a negative influence on chimpanzee abundance, hunting pressure had a weak positive influence on chimpanzee abundance, and all other coefficients were close to zero (Fig. 6). The model averaged coefficients of the zero part of the zero inflated negative binomial models on chimpanzee abundance showed that the likelihood of no chimpanzee occurrence increased strongly with the market integration (Fig. 7).

Our results revealed that including human socioeconomic factors other than human population density alone increased our capacity to model wild mammal abundance in our study area in Guinea. All human population factors we considered in our analysis were deduced from the framework of wild mammals as economic goods. In the case of the analysis on mixed species abundance, the best model did not contain human population density at all but was made up of taboo influence, market integration, hunting pressure, and the environmental control predictors. Chimpanzee abundance was best modeled by market integration alone.

\section{Implications}

\section{Conservation}

Although the transect data revealed promising wild mammal abundance in the study area, our results point to serious issues for the WCF biodiversity offset project in the study region. First, the CFs in the study area were not enhancing wild mammal 
Fig. 4. Influence of market integration on wild mammal abundance. Plots show the effect of market integration on species abundance for each species separately. Abundance refers to the number sightings per kilometer transect. Observed abundances are shown as points, and the estimated abundances are shown as dotted lines.
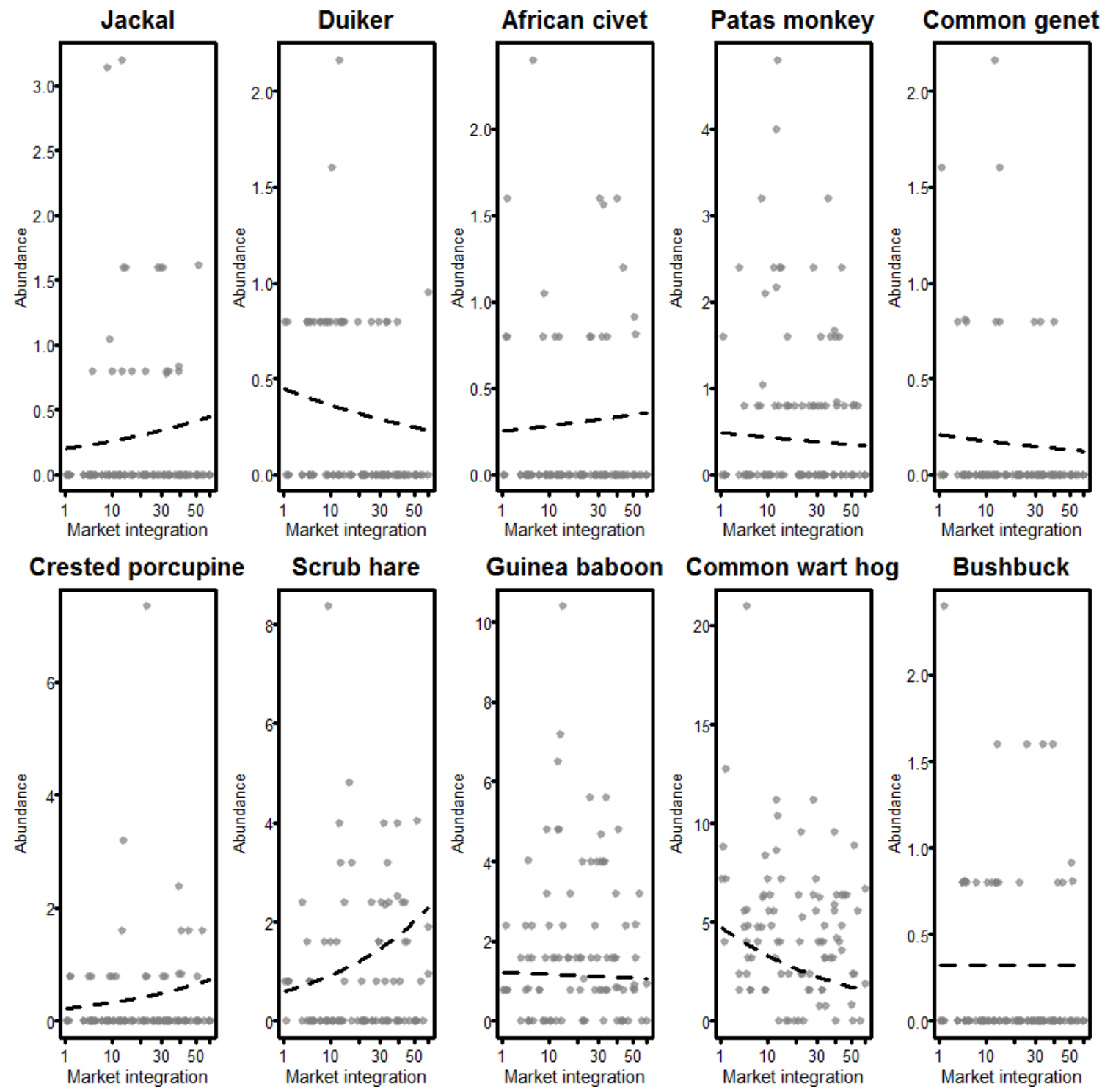

abundance. Instead, they had a negative effect on wild mammal species abundance and did not influence chimpanzee abundance. This might be due to different reasons. For example, the knowledge of the classified forest boundaries was not widespread in the study area, and CF boundaries were not respected, with nine villages being located within them. Furthermore, the success of protected areas in conserving wild mammals depends on considerable effort, especially in law enforcement (Bruner et al. 2001, Tranquilli et al. 2012, 2014). Such effort is lacking in the study area. Our results suggest that the village communities were more successful in controlling the exploitation of wild mammals than the government was in the CFs. When the government does not sufficiently invest in monitoring and controlling its protected areas, those areas might be considered as common ground by the communities surrounding them. The mechanism of the "tragedy of the commons" (Hardin 1968) then leads to overexploitation. This indicates that protected areas without sufficient monitoring and controlling efforts are worse for the conservation of wild mammals than giving the land as property to the local communities (Coase 1960). Or vice versa, if areas with restricted access should remain an important element of conservation projects, the functional regulation and monitoring of restricted access to the area is essential for the protection of wild mammals. Second, the local population relied on slash-and-burn cultivation for their subsistence agriculture. This practice has a detrimental influence on the environment, and the locations of the fields had a strong negative effect on wild mammal species abundance in the 
Table 6. Result of the mixed effects Poisson regression on wild mammal abundance with population density and the control predictors.

\begin{tabular}{|c|c|c|c|c|}
\hline \multicolumn{5}{|l|}{ Observations } \\
\hline \multicolumn{5}{|l|}{938 abundance values } \\
\hline \multicolumn{5}{|l|}{ Random effects } \\
\hline & $N$ & Standard deviation & $\mathrm{x}^{2}$ & $P$ value \\
\hline Species intercept & 10 & 1.0851 & & \\
\hline Transect intercept & 98 & 0.498 & & \\
\hline Species: Normalized Differenced Vegetation Index ${ }^{\dagger}$ & & 0.000 & 0.000 & 1.000 \\
\hline Species: Distance next field & & 0.000 & 0.000 & 1.000 \\
\hline Species: Distance next river ${ }^{\star}$ & & 0.000 & 0.000 & 1.000 \\
\hline Species: Distance next road ${ }^{*}$ & & 0.089 & 0.367 & 0.545 \\
\hline Species: Share classified forest ${ }^{\dagger}$ & & 0.000 & 0.000 & 1.000 \\
\hline Species: Population density ${ }^{\S}$ & & 0.102 & 2.115 & 0.146 \\
\hline \multicolumn{2}{|l|}{ Fixed effects } & Estimate & Standard error & $P$ value \\
\hline Intercept & & -7.852 & 0.352 & $<0.001$ \\
\hline Normalized Differenced Vegetation Index ${ }^{\dagger}$ & & 0.064 & 0.063 & 0.306 \\
\hline Distance next field & & 0.209 & 0.083 & 0.012 \\
\hline Distance next river ${ }^{*}$ & & -0.013 & 0.067 & 0.846 \\
\hline Distance next road & & -0.014 & 0.083 & 0.869 \\
\hline Share classified forest ${ }^{\dagger}$ & & -0.069 & 0.067 & 0.297 \\
\hline Population density $^{\S}$ & & -0.013 & 0.079 & 0.866 \\
\hline $\begin{array}{l}z \text {-transformed } \\
s_{\text {square root and then } z \text {-transformed }} \\
\text { square root transformed after subtraction of minim }\end{array}$ & & & & \\
\hline
\end{tabular}

Fig. 5. Coefficients of the fixed effects of the mixed effects Poisson regression models on mixed species abundance. The values of the coefficients are shown on the x-axis, and the names of the predictors are shown on the y-axis. The number of times each predictor was included in a model is shown in parentheses behind the predictor name. The darker the coefficient, the higher the Akaike weight of the model it was taken from. All coefficients were standardized by the partial standard deviation of the respective predictors to be comparable across models and to allow for the deduction of meaningful model averaged coefficients (Cade 2015). (NDVI: Normalized Differenced Vegetation Index) $\nmid z$-transformed; $\$$ square root and then z-transformed; §square root transformed after subtraction of minimum and then $\mathrm{z}$-transformed

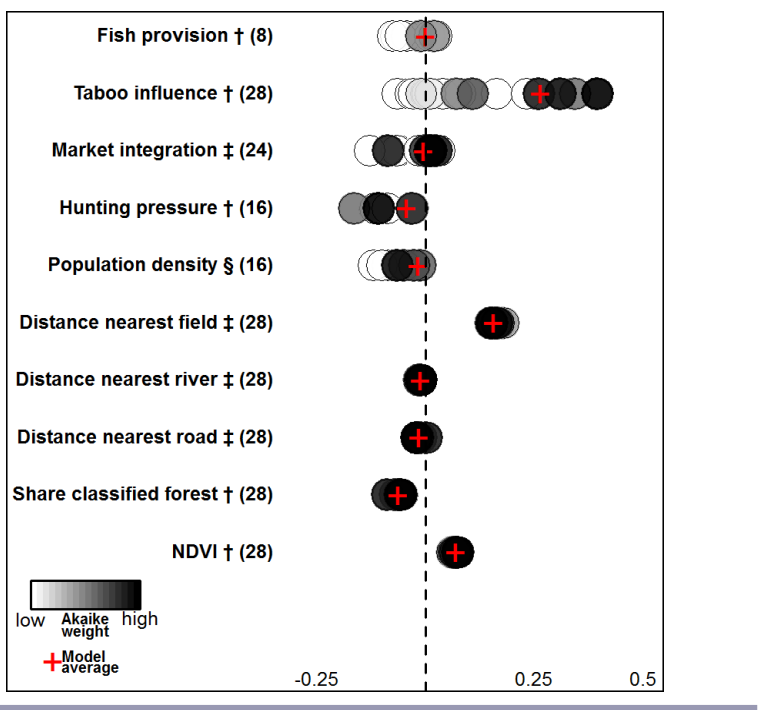

Fig. 6. Coefficients of the count part of the zero inflated negative binomial regression models on chimpanzee abundance. The values of the coefficients are shown on the x-axis, and the names of the predictors are shown on the y-axis. The number of times each predictor was included in a model is shown in parentheses behind the predictor name. The darker the coefficient, the higher the Akaike weight of the model it was taken from. All coefficients were standardized by the partial standard deviation of the respective predictors to be comparable across models and to allow for the deduction of meaningful model averaged coefficients (Cade 2015). (NDVI: Normalized Differenced Vegetation Index $) \dagger z$-transformed; $\$$ square root and then z-transformed;§square root transformed after subtraction of minimum and then z-transformed

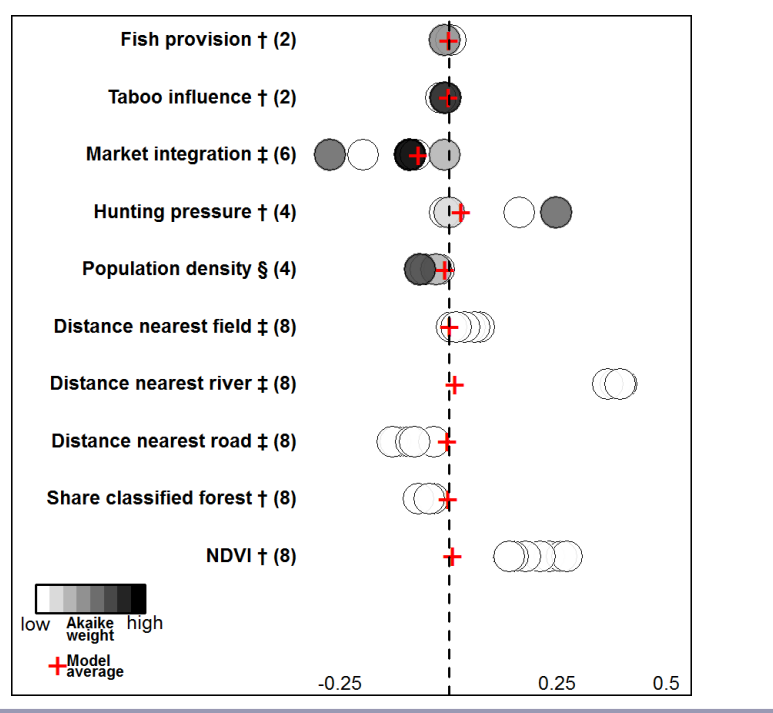


Table 7. Result of multimodel inference on zero inflated negative binomial regression on the abundance of chimpanzees (AIC: Akaike information criterion; VIF: Variance Inflation Factor).

\begin{tabular}{|c|c|c|c|c|c|c|c|}
\hline Model & Rank & $\begin{array}{c}\text { Confidence } \\
\text { set }\end{array}$ & $\mathrm{AIC}$ & delta AIC & $\begin{array}{l}\text { Akaike } \\
\text { weight }\end{array}$ & cum & $\max . \mathrm{VIF}$ \\
\hline Market integration & 1 & yes & 525.519 & 0.000 & 0.414 & 0.414 & \\
\hline Taboo influence & 2 & yes & 527.600 & 2.081 & 0.146 & 0.560 & \\
\hline Population density & 3 & yes & 528.096 & 2.577 & 0.114 & 0.674 & \\
\hline Hunting pressure + Market integration & 4 & yes & 528.220 & 2.702 & 0.107 & 0.781 & 2.793 \\
\hline Fish supply & 5 & yes & 528.774 & 3.255 & 0.081 & 0.863 & \\
\hline Market integration + Population density & 6 & yes & 529.476 & 3.957 & 0.057 & 0.92 & 4.101 \\
\hline Hunting pressure & 7 & yes & 530.214 & 4.696 & 0.04 & 0.959 & \\
\hline Market integration + Control & 8 & no & 531.878 & 6.359 & 0.017 & 0.977 & 1.931 \\
\hline Hunting pressure + Market integration + Control & 9 & no & 534.143 & 8.624 & 0.006 & 0.982 & 3.569 \\
\hline 1 & 10 & no & 534.304 & 8.785 & 0.005 & 0.987 & \\
\hline Market integration + Population density + Control & 11 & no & 534.741 & 9.222 & 0.004 & 0.991 & 5.613 \\
\hline Fish supply + Control & 12 & no & 535.622 & 10.103 & 0.003 & 0.994 & 1.910 \\
\hline Taboo influence + Control & 13 & no & 535.685 & 10.167 & 0.003 & 0.997 & 1.976 \\
\hline Population density + Control & 14 & no & 536.268 & 10.749 & 0.002 & 0.998 & 1.898 \\
\hline Control & 15 & no & 537.899 & 12.380 & 0.001 & 0.999 & 1.606 \\
\hline Hunting pressure + Control & 16 & no & 538.271 & 12.752 & 0.001 & 1.000 & 1.956 \\
\hline
\end{tabular}

Control predictors are share classified forests, distance nearest road, distance nearest river, distance nearest field, and Normalized Differenced Vegetation Index.

Fig. 7. Coefficients of the zero part of the zero inflated negative binomial regression models on chimpanzee occurrence. This part of the model estimates the probability of having zero in the response variable. The values of the coefficients are shown on the $\mathrm{x}$-axis and the names of the predictors on the $\mathrm{y}$-axis. The number of times each predictor was included in a model is shown in parentheses behind the predictor name. The darker the coefficient, the higher the Akaike weight of the model it was taken from. All coefficients were standardized by the partial standard deviation of the respective predictors to be comparable across models and to allow for the deduction of meaningful model averaged coefficients (Cade 2015). (NDVI: Normalized Differenced Vegetation Index) $†$ z-transformed; $\$$ square root and then z-transformed; §square root transformed after subtraction of minimum and then $\mathrm{z}$-transformed

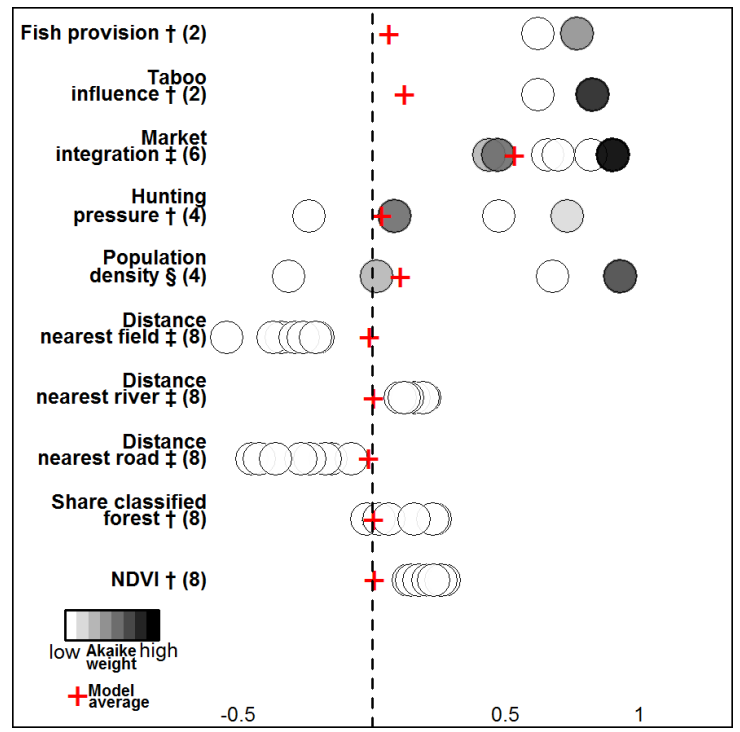

study area. It remains unclear if this effect was due to habitat destruction or to conflicts with wild mammals that are attracted by field crops. In any case, long-term conservation planning in the area is constrained if the fields are relocated regularly. Protecting the crops without harming wild mammals, for example by erecting fences around the fields, might prove an efficient tool for wild mammal conservation in the study area (Agrawal et al. 2016). Finally, although the human population was poor and suffered from animal protein deficiency, some did not eat potential game (especially common wart hogs provide plenty of meat) because of religious beliefs. In fact, food taboos had a positive effect on wild mammal species abundance. As suggested by other studies, our results support the notion that food taboos can work as resource management tools to protect wild mammal species (McDonald 1977, Balée 1985, Pezzuti et al. 2010, Read et al. 2010, Luzar et al. 2012). The option to appeal to such beliefs, in cooperation with local religious authorities, should seriously be considered. Unlike Junker et al. (2015), we did not find an effect of fish availability on wild mammal abundance. This suggests that fish availability did not work as a substitute for wild mammal meat in the study area. One reason for this missing effect might be that the amount of fish provided in the study area is not sufficient to substitute bushmeat. Furthermore, the accessibility of the transects did not influence wild mammal abundance. This indicates that the roads might not have affected the remoteness of the area and were used mainly by locals. The effect of hunting was ambiguous. On the one hand, wild mammal species abundance decreased with increasing hunting pressure. On the other hand, chimpanzee abundance increased with growing hunting pressure. The reason for this difference might be that chimpanzees profit from less competition from other wild mammals in areas with increased hunting pressure. Our results regarding chimpanzees are especially interesting because they suggest that in our study area, chimpanzee abundance was not obviously influenced by environmental factors but mainly by human population factors. Especially, the market integration had 
a clearly negative influence. The situation was similar for common wart hogs. Their abundance decreased strongly with increasing market integration. It seems that for species that lack a local demand, such as chimpanzees and common wart hogs, the market integration of the population compensates for this missing demand and puts pressure on these animals. For other species, such as scrub hares, the same mechanism might have the opposite effect: their abundance increases with market integration. Probably, hunting scrub hare is substituted with buying cheap chicken, which is available only on the market. So overall, the market integration provides alternative sources of income to the local population; however, it also provides additional incentives to exploit wild mammals. If in the long run, the economic development and the market integration of the local population, which was very low, even for Guinean standards, should eventually catch up with the rest of the country, a strategy targeting this issue is necessary. A promising strategy for the WCF biodiversity offset might be to provide alternative sources of income for the local population.

\section{Outlook}

Our results revealed that although environmental factors were important to understanding the abundance of wild mammal species in our study area, it was fundamental to also account for human population factors. In fact, only two of our environmental predictors (NDVI and distance to nearest river) were purely environmental. The other three (distance to nearest road, distance to nearest field, share classified forests) represented human factors. For the chimpanzees, the environmental control predictors did not influence their abundance at all. All in all, this suggests that wild mammal abundance was influenced more by human factors than by environmental factors in our study area. The crucial reason for considering factors other than human population density when estimating the effect of the human population on wild mammals consists not only of optimizing the goodness of fit, as it is shown in our multimodel inference analysis (Table 4, Table 7). Rather, the main reason is to improve our understanding of the relationships between the human population and the wild mammals. This is best exemplified when comparing the best model (Table 5) and the model of rank 8 (Table 6) from our multimodel inference on the mixed species abundance (Table 4). In the best model, wild mammal species abundance was a function of market integration, taboo influence, hunting pressure, and the control predictors. In the model of rank 8 (with a delta AIC of 7.24), wild mammal species abundance was a function of population density and the control predictors. The conclusions drawn from the two models differ substantially. When looking at the population density model (Table 6), one would conclude that the human population had no influence on wild mammal abundance. But the best model, where human population density was replaced by hunting pressure, taboo influence, and market integration, showed a different picture (Table 5, Fig. 4): increasing taboo influence came along with increases in wild mammal abundance. Our analysis furthermore revealed that market integration negatively influenced the abundance of duikers, patas monkeys, common genets, and common wart hogs, positively influenced the abundance of jackals, African civets, crested porcupines, and scrub hares, and had no obvious influence on the abundance of Guinea baboons and bushbucks. Therefore, when planning conservation activities in the area, market activities of the human population must be taken into account very carefully, avoiding the negative effects (additional incentives to exploit wild mammals) and using the positive ones (substitution of wild mammal products with products available on the market). Our results were expectable given that wild mammals and humans are part of a common social-ecological system and influence each other. The framework of wild mammals as economic goods within a social-ecological system is an appropriate tool to help detect important factors that drive the relationship between wild mammals and humans in a diverse range of settings.

Responses to this article can be read online at: http://www.ecologyandsociety.org/issues/responses. $\mathrm{php/9516}$

\section{Acknowledgments:}

First, we thank the Guinean authorities for providing us with their support and all necessary documents to work in the country. Second, we thank the local population for its kind cooperation. Third, we thank our Guinean assistants Salian Traore, Mohammed Kaba Abdoulaye Diallo, and Ousmane Diallo for their work and advice. Finally, we thank Christophe Boesch for his consultancy and for reviewing the work. This work was funded and facilitated by the Wild Chimpanzee Foundation (WCF) and Deutscher Akademischer Austauschdienst (DAAD).

\section{LITERATURE CITED}

Agrawal, P. K., A. Verghese, S. R. Krishna, and K. Subaharan, editors. 2016. Human animal conflict in agro-pastoral context: issues \& policies. Indian Council of Agricultural Research, New Delhi, India.

Ayalew, B., B. Afework, and M. Balakrishnan. 2013. Home range and movement patterns of African civet Civettictis civetta in Wondo Genet, Ethiopia. Small Carnivore Conservation 48:83-86.

Baayen, R. H. 2008. Analyzing linguistic data. Cambridge University Press, Cambridge.

Balée, W. 1985. Ka'apor ritual hunting. Human Ecology 13 (4):485-510. http://dx.doi.org/10.1007/BF01531156

Barnett, A. A., and M. L. Prangley. 1997. Mammalogy in the Republic of Guinea: an overview of research from 1946 to 1996, a preliminary check-list and a summary of research recommendations for the future. Mammal Review 27(3):115-164. http://dx.doi.org/10.1111/j.1365-2907.1997.tb00376.x

Barr, D. J., R. Levy, C. Scheepers, and H. J. Tily. 2013. Random effects structure for confirmatory hypothesis testing: Keep it maximal. Journal of Memory and Language 68:255-278. http:// dx.doi.org/10.1016/j.jm1.2012.11.001

Bates, D., M. Maechler, B. Bolker, and S. Walker. 2015. Fitting linear mixed-effects models using lme4. Journal of Statistical Software 67(1):1-48. http://dx.doi.org/10.18637/jss.v067.i01

Bennett, E. L. 2002. Is there a link between wild meat and food security? Conservation Biology 16(3):590-592. http://dx.doi. org/10.1046/i.1523-1739.2002.01637.x 
Birrell, J. 1992. Deer and deer farming in medieval England. Agricultural History Review 40(2):112-126.

Brashares, J. S., C. D. Golden, K. Z. Weinbaum, C. B. Barrett, and G. V. Okello. 2011. Economic and geographic drivers of wildlife consumption in rural Africa. Proceedings of the National Academy of Sciences of the United States of America 108 (34):13931-13936. http://dx.doi.org/10.1073/pnas.1011526108

Briceño-Linares, J., J. P. Rodriguez, K. M. Rodriguez-Clark, F. Rojas Suarez, P. A. Millan, E. G. Vittori, and M. CarrascoMunoz. 2011. Adapting to changing poaching intensity of yellowshouldered parrot (Amazona barbadensis) nestlings in Margarita Island, Venezuela. Biological Conservation 144:1188-1193. http:// dx.doi.org/10.1016/j.biocon.2010.12.010

Brncic, T., B. Amarasekaran, A. McKenna, R. Mundry, and H. S. Kühl. 2015. Large mammal diversity and their conservation in the human-dominated land-use mosaic of Sierra Leone. Biodiversity and Conservation 24(10):2417-2438. http://dx.doi. org/10.1007/s10531-015-0931-7

Brugiere, D., and R. Kormos. 2009. Review of the protected area network in Guinea, West Africa, and recommendations for new sites for biodiversity conservation. Biodiversity and Conservation 18:847-868. http://dx.doi.org/10.1007/s10531-008-9508-Z

Bruner, A. G., R. E. Gullison, R. E. Rice, and G. A. B. da Fonseca. 2001. Effectiveness of parks in protecting tropical biodiversity. Science 291:125-128. http://dx.doi.org/10.1126/science.291.5501.125

Buckland, S. T., D. R. Anderson, K. P. Burnham, J. L. Laake, D. L. Borchers, and L. Thomas. 2001. Introduction to distance sampling estimating abundance of biological populations. Oxford University Press.

Burnham, K. P., and D. R. Anderson, editors. 2002. Model selection and multimodel inference. Second edition. Springer, Berlin, Germany. http://dx.doi.org/10.1007/b97636

Cade, B. S. 2015. Model averaging and muddled multimodel inferences. Ecology 96(9):2370-2382. http://dx.doi.org/10.1890/14-1639.1

Campbell, B., and J. Clapp. 1995. Guinea's economic performance under structural adjustment: importance of mining and agriculture. Journal of Modern African Studies 33(3):425-449. http://dx.doi.org/10.1017/S0022278X00021194

Campbell, L. M., and A. Vainio-Mattila. 2003. Participatory development and community-based conservation: opportunities missed for lessons learned? Human Ecology 31(3):417-437. http:// dx.doi.org/10.1023/A:1025071822388

Chammaillé-Jammes, S., M. Valeix, and H. Fritz. 2007. Managing heterogeneity in elephant distribution: interactions between elephant population density and surface-water availability. Journal of Applied Ecology 44(3):625-633. http://dx.doi. org/10.1111/j.1365-2664.2007.01300.x

Chardonnet, P., B. des Clers, J. Fischer, R. Gerhold, F. Jori, and F. Lamarque. 2002. The value of wildlife. Scientific and Technical Review of the Office International des Epizooties 21(1):15-51.

Chazdon, R. L., C. A. Harvey, O. Komar, D. M. Griffith, B. G. Ferguson, M. Martínez-Ramos, H. Morales, R. Nigh, L. SontoPinto, M. Van Breugel, and S. M. Philpott. 2009. Beyond reserves: a research agenda for conserving biodiversity in human-modified tropical landscapes. Biotropica 41(2):142-153. http://dx.doi. org/10.1111/j.1744-7429.2008.00471.x

Coase, R. H. 1960. The problem of social cost. Journal of Law \& Economics 3:1-44. http://dx.doi.org/10.1086/466560

Craigie, I. D., J. E. M. Bailiie, A. Balmford, C. Carbone, B. Collen, R. E. Green, and J. M. Hutton. 2010. Large mammal population declines in Africa's protected areas. Biological Conservation 143:2221-2228. http://dx.doi.org/10.1016/j.biocon.2010.06.007

Davies, G. 2002. Bushmeat and international development. Conservation Biology 16(3):587-589. http://dx.doi.org/10.1046/ j.1523-1739.2002.01636.X

DeGama-Blanchet, H. N., and L. M. Fedigan. 2006. The effects of forest fragment age, isolation, size, habitat type, and water availability on monkey density in a tropical dry forest. Pages 165 188 in A. Estrada, P. Garber, M. Pavelka, and L. Luecke, editors. New perspectives in the study of Mesoamerican primates: distribution, ecology, behavior and conservation. Kluwer Academic/Plenium Publishers, New York, USA. http://dx.doi. org/10.1007/0-387-25872-8_8

de Groot, R. S., M. A. Wilson, and R. M. J. Boumans. 2002. A typology for the classification, description and valuation of ecosystem functions, goods and services. Ecological Economics 41:393-408. http://dx. doi.org/10.1016/S0921-8009(02)00089-7

Develey, P. F., and P. C. Stouffer. 2001. Effects of roads on movements by understory birds in mixed-species flocks in central Amazonian Brazil. Conservation Biology 15(5):1416-1422.

Elith, J., and J. R. Leathwick. 2009. Species distribution models: ecological explanation and prediction across space and time. Annual Review of Ecology, Evolution, and Systematics 40(1):677697. http://dx.doi.org/10.1146/annurev.ecolsys.110308.120159

Estes, R. D. 1991. The behaviour guide to African mammals. University of California Press, Berkely and Los Angeles, California, USA.

Field, A. 2005. Discovering statistics using SPSS. Sage Publications, London, UK.

Fox, J., and S. Weisberg. 2011. An R companion to applied regression. Second edition. Sage Publications, Inc., Thousand Oaks, California, USA.

Fürtbauer, I., R. Mundry, M. Heistermann, O. Schülke, and J. Ostner. 2011. You mate, I mate: macaque females synchronize sex not cycles. PLoS ONE 6(10):e26144. http://dx.doi.org/10.1371/ journal.pone.0026144

Gardner, T. A., T. Caro, E. B. Fitzherbert, T. Banda, and P. Lalbhai. 2007. Conservation value of multiple-use areas in East Africa. Conservation Biology 21(6):1516-1525. http://dx.doi. org/10.1111/j.1523-1739.2007.00794.X

Gardner, R., E. Ostrom, and J. M. Walker. 1990. The nature of common-pool resource problems. Rationality and Society 2 (3):335-358. http://dx.doi.org/10.1177/1043463190002003005

Guisan, A., and W. Thuiller. 2005. Predicting species distribution: offering more than simple habitat models. Ecology Letters 8:9931009. http://dx.doi.org/10.1111/j.1461-0248.2005.00792.x 
Ham, R. 1998. Nationwide chimpanzee census and large mammal survey: Republic of Guinea. European Union, Conakry, Guinea.

Hardin, G. 1968. The tragedy of the commons. Science 162 (3859):1243-1248. http://dx.doi.org/10.1126/science.162.3859.1243

Holben, B. N. 1986. Characteristics of maximum-value composite images from temporal AVHRR data. International Journal of Remote Sensing 7(11):1417-1434. http://dx.doi. org/10.1080/01431168608948945

International Finance Corporation (IFC). 2012. Performance standards on environmental and social sustainability.

International Union for Conservation of Nature and United Nations World Conservation Monitoring Centre (IUCN and UNEP-WCMC). 2016. The world database on protected areas. Cambridge, UK. [online] URL: http://www.protectedplanet.net

Iwamura, T., E. F. Lambin, K. M. Silvius, J. B. Luzar, and J. M. V. Fragoso. 2014. Agent-based modeling of hunting and subsistence agriculture on indigenous lands: understanding interactions between social and ecological systems. Environmental Modelling \& Software 58:109-127. http://dx.doi.org/10.1016/j. envsoft.2014.03.008

Jackman, S. 2015. pscl: classes and methods for R developed in the political science computational laboratory, Stanford University. R package version 1.4.9. Stanford University, Stanford, California, USA. [online] URL: http://pscl.stanford. edul

Jarvis, A., H. I. Reuter, A. Nelson, and E. Guevara. 2008. Holefilled seamless SRTM data V4. International Centre for Tropical Agriculture (CIAT). [online] URL: http://srtm.csi.cgiar.org

Juffe-Bignoli, D., N. D. Burgess, H. Bingham, E. M. S. Belle, M. G. de Lima, M. Deguignet, B. Bertzky, A. N. Milam, J. MartinezLopez, E. Lewis, A. Eassom, S. Wicander, J. Geldmann, A. van Soesbergen, A. P. Arnell, B. O'Connor, S. Park, Y. N. Shi, F. S. Danks, B. MacSharry, and N. Kingston. 2014. Protected planet report 2014. UNEP-WCMC, Cambridge, UK.

Junker, J., C. Boesch, R. Mundry, C. Stephens, M. Lormie, C. Tweh, and H. S. Kühl. 2015. Education and access to fish but not economic development predict chimpanzee and mammal occurrence in West Africa. Biological Conservation 182:27-35. http://dx.doi.org/10.1016/j.biocon.2014.11.034

Kareiva, P., and M. Marvier. 2014. The evidence and values underlying "new conservation". Trends in Ecology \& Evolution 28:131-132.

Kuehl, H., F. Maisels, M. Ancrenaz, and E. A. Williamson. 2008. Lignes directrices pour de meilleures pratiques en matière d'inventaire et de suivi des populations de grands singes. Groupe de spécialistes des primates de la CSE de l'UICN, Gland, Suisse.

Laakso, A., and T. Tyynela. 2006. Non-wood forest benefits and agroforestry practices in the Fouta Djallon highlands of Guinea. Nordic Journal of African Studies 15(4):579-590.

Laurance, W. F., B. M. Croes, L. Tchignoumba, S. A. Lahm, A. Alonso, M. E. Lee, P. Campbell, and C. Ondzeano. 2006. Impacts of roads and hunting on central African rainforest mammals. Conservation Biology 20(4):1251-1261. http://dx.doi.org/10.1111/ j.1523-1739.2006.00420.x
Luzar, J. B., K. M. Silvius, and J. M. V. Fragoso. 2012. Church affiliation and meat taboos in indigenous communities of Guyanese Amazonia. Human Ecology 40(6):833-845. http://dx. doi.org/10.1007/s10745-012-9521-4

Madhusudan, M. D. 2005. The global village: linkages between international coffee markets and grazing by livestock in a south Indian wildlife reserve. Conservation Biology 19(2):411-420. http://dx.doi.org/10.1111/j.1523-1739.2005.00330.x

Malcolm, J. R., and J. C. Ray. 2000. Influence of timber extraction routes on central African small-mammal communities, forest structure, and tree diversity. Conservation Biology 14(6):16231638.

Marvier, M. 2014. New conservation is true conservation. Conservation Biology 28:1-3. http://dx.doi.org/10.1111/cobi.12206

McCullagh, P., and J. A. Nelder. 1996. Generalized linear models. Chapman and Hall, London, UK.

McDonald, D. R. 1977. Food taboos: a primitive environmental protection agency (South America). Anthropos 72:734-748.

Milledge, S. A. H. 2007. Illegal killing of African rhinos and horn trade, 2000-2005: the era of resurgent markets and emerging organized crime. Pachyderm 43:96-107.

Milner-Gulland, E. J., E. L. Bennett, and the SCB 2002 Annual meeting wild meat group. 2003. Wild meat: the bigger picture. Trends in Ecology \& Evolution 18(7):351-357. http://dx.doi. org/10.1016/S0169-5347(03)00123-X

Ministère de l'agriculture et des ressources animales de la République de Guinée. 1999. Code forestier.

Mori, E., S. Lovari, A. Sforzi, G. Romeao, C. Pisani, A. Massolo, and L. Fattorini. 2014. Patterns of spatial overlap in monogamous large rodent, the crested porcupine. Behavioural Processes 107:112-118. http://dx.doi.org/10.1016/j.beproc.2014.08.012

Musgrave, R. A., and P. B. Musgrave. 1989. Public finance in theory and practice. McGraw-Hill Book Company, Singapore, Malaysia.

Nijman, V. 2010. An overview of international wildlife trade from Southeast Asia. Biodiversity and Conservation 19:1101-1114. http://dx.doi.org/10.1007/s10531-009-9758-4

Nijman, V., and C. R. Shepherd. 2007. Trade in non-native, CITES-listed, wildlife in Asia, as exemplified by the trade in freshwater turtles and tortoises (Chelonidae) in Thailand. Contributions to Zoology 76(3):207-212.

N'Goran, P. K., C. Boesch, R. Mundry, E. K. N'Goran, I. Herbinger, F. A. Yapi, and H. S. Kühl. 2012. Hunting, law enforcement, and African primate conservation. Conservation Biology 26(3):565-571. http://dx.doi.org/10.1111/j.1523-1739.2012.01821. $\underline{\mathrm{X}}$

Oindo, B. O., and A. K. Skidmore. 2002. Interannual variability of NDVI and species richness in Kenya. International Journal of Remote Sensing 23(2):285-298. http://dx.doi.org/10.1080/01431$\underline{160010014819}$

Osborne, P. E., J. C. Alonso, and R. G. Bryant. 2001. Modelling landscape-scale habitat use using GIS and remote sensing: a case 
study with great bustards. Journal of Applied Ecology 38:458-471. http://dx.doi.org/10.1046/j.1365-2664.2001.00604.x

Ostrom, E. 1990. Governing the commons. Cambridge University Press, Cambridge.

Ostrom, E. 2007. A diagnostic approach for going beyond panaceas. Proceedings of the National Academy of Sciences of the United States of America 104(39):15181-15187. http://dx.doi. org/10.1073/pnas.0702288104

Ostrom, E. 2009. A general framework for analyzing sustainability of social-ecological systems. Science 325:419-422. http://dx.doi.org/10.1126/science.1172133

Patzelt, A. 2013. The social system of Guinea baboons (Papio papio) with a focus on male-male relationships. Dissertation. Georg-August-Universitäg, Göttingen, Germany.

Pezzuti, J. C. B., J. P. Lima, D. F. Lima, D. F. da Silva, and A. Begossi. 2010. Uses and taboos of turtles and tortoises along Rio Negro, Amazon Basin. Journal of Ethnobiology 30(1):153-168. http://dx.doi.org/10.2993/0278-0771-30.1.153

Pimm, S. L., and P. Raven. 2000. Biodiversity: extinction by numbers. Nature 403:843-845. http://dx.doi.org/10.1038/35002708

Prescott-Allen, C., and R. Prescott-Allen. 1986. The first resource. World Wildlife Fund, Binghamton, New York, USA.

Primate Info Net. 2016. Patas monkey Erythrocebus patas. [online] URL: http://pin.primate.wisc.edu/factsheets/entry/patas_monkey

Protected Planet. 2016. Guinea Africa. [online] URL: http://www. protectedplanet.net/country/GN

R Development Core Team. 2016. R: a language and environment for statistical computing. $\mathrm{R}$ Foundation for Statistical Computing, Vienna, Austria. [online] URL: http://www.Rproject.org

Rapideye. 2016. Ortho product (Level 3A). [online] URL: http:// web-dev.rapideye.de/rapideye/all-products/ortho.htm

Read, J. M., J. M. V. Fragoso, K. M. Silvius, J. Luzar, H. Overman, A. Cummings, S. T. Giery, and L. F. de Oliveira. 2010. Space, place, and hunting patterns among indigenous peoples of the Guyanese Rupununi Region. Journal of Latin American Geography 9(3):213-243. http://dx.doi.org/10.1353/lag.2010.0030

Redfern, J. V., R. Grant, H. Biggs, and W. M. Getz. 2003. Surfacewater constraints on herbivore foraging in the Kruger National Park, South Africa. Ecology 84(8):2092-2107. http://dx.doi. org/10.1890/01-0625

Regnaut, S., and C. Boesch. 2012. Offset strategy for the Guinean Aluminia Project. Wild Chimpanzee Foundation, Conakry, Republic of Guinea.

Schielzeth, H. 2010. Simple means to improve the interpretability of regression coefficients. Methods in Ecology and Evolution 1:103-113. http://dx.doi.org/10.1111/j.2041-210X.2010.00012.x

Schielzeth, H., and W. Forstmeier. 2009. Conclusions beyond support: overconfident estimates in mixed models. Behavioral Ecology 20:416-420. http://dx.doi.org/10.1093/beheco/arn145

Sirois, M.-C., H. A. Margolis, and C. Camiré. 1998. Influence of remnant trees on nutrients and fallow biomass in slash and burn agroecosystems in Guinea. Agroforestry Systems 40:227-246. http://dx.doi.org/10.1023/A:1006093329468

Soulé, M. 2013. The "new conservation". Conservation Biology 27:895-897. http://dx.doi.org/10.1111/cobi.12147

Tews, J., U. Brose, V. Grimm, K. Tielbörger, M. C. Wichmann, M. Schwager, and F. Jeltsch. 2004. Animal species diversity driven by habitat heterogeneity/diversity: the importance of keystone structures. Journal of Biogeography 31:79-92. http://dx.doi. org/10.1046/j.0305-0270.2003.00994.x

Thomas, L., S. T. Buckland, E. A. Rexstad, J. L. Laake, S. Strindberg, S. L. Hedley, J. R. B. Bishop, T. A. Marques, and K. P. Burnham. 2010. Distance software: design and analysis of distance sampling surveys for estimating population size. Journal of Applied Ecology 47:5-14. http://dx.doi.org/10.1111/ j.1365-2664.2009.01737.x

Tilmann, D., R. M. May, C. L. Lehman, and M. A. Nowak. 1994. Habitat destruction and the extinction debt. Nature 371:65-66. http://dx.doi.org/10.1038/371065a0

TRAFFIC. 2008. What's driving the wildlife trade? A review of expert opinion on economic and social drivers of the wildlife trade and trade control efforts in Cambodia, Indonesia, Lao PDR and Vietnam. East Asia and Pacific Region Sustainable Development Discussion Papers. East Asia and Pacific Region Sustainable Development Department, World Bank, Washington, D.C., USA.

Tranquilli, S., M. Abedi-Lartey, K. Abernethy, F. Amsini, A. Asamoah, C. Balangtaa, S.Blake, E. Bouanga, T. Breuer, T. M. Brncic, et al. 2014. Protected areas in tropical Africa: assessing threats and conservation activities. PLOS ONE 9(12):e114154. http://dx.doi.org/10.1371/journal.pone.0114154

Tranquilli, S., M. Abedi-Lartey, F. le Amsini, L. Arranz, A. Asamoah, O. Babafemi, N. Barakabuye, G. Campbell, R. Chancellor, T. R. B. Davenport, et al. 2012. Lack of conservation effort rapidly increases African great ape extinction risk. Conservation Letters 5:48-55. http://dx.doi.org/10.1111/ j.1755-263X.2011.00211.X

United Nations Development Programme (UNDP). 2016. Human Development Index (HDI). [online] URL: http://hdr. undp.org/en/content/human-development-index-hdi

van Etten, J. 2015. gdistance: distances and routes on geographical grids. R package version 1.1-9. [online] URL: http://CRAN.Rproject.org/package $=$ gdistance

van Vliet, N., J. Fa, and R. Nasi. 2015. Managing hunting under uncertainty: from one-off ecological indicators to resilience approaches in assessing the sustainability of bushmeat hunting. Ecology and Society 20(3):7. http://dx.doi.org/10.5751/ES-07669-200307

van Wilgen, B. W., and H. C. Biggs. 2011. A critical assessment of adaptive ecosystem management in a large savanna protected area in South Africa. Biological Conservation 144:1179-1187. http://dx.doi.org/10.1016/j.biocon.2010.05.006

Western, D. 1975. Water availability and its influence on the structure and dynamics of a savannah large mammal community. African Journal of Ecology 13(3-4):265-286. http://dx.doi. org/10.1111/j.1365-2028.1975.tb00139.x 
Wild Chimpanzee Foundation (WCF). 2015. Complementary primates study $\mathrm{CBG}$ expansion project.

Wild Chimpanzee Foundation (WCF). 2016. WCF Mission. [online] URL: http://www.wildchimps.org/index.html

Wildpro. 2016. Lepus saxatilis - Scrub hare. [online] URL: http:// wildpro.twycrosszoo.org/S/0MLagomorph/Leporidae/lepus/

Lepus saxatilis.htm\#Social

World Bank. 2016a. Land area (sq. km). [online] URL: $\underline{\text { htp:// }}$ data.worldbank.org/indicator/AG.LND.TOTL.K2

World Bank. 2016b. GDP per capita (current US\$). [online] URL: http://data.worldbank.org/indicator/NY.GDP.PCAP.CD

World Bank. 2016c. Life expectancy at birth, total (years). [online] URL: http://data.worldbank.org/indicator/SP.DYN.LE00.IN

World Bank. 2016d. Mineral rents (\% of GDP). [online] URL: http://data.worldbank.org/indicator/NY.GDP.MINR.RT.ZS

World Bank. 2016e. Forest rents (\% of GDP). [online] URL: http://data.worldbank.org/indicator/NY.GDP.FRST.RT.ZS

World Bank. 2016f. Urban population (\% of total). [online] URL: http://data.worldbank.org/indicator/SP.URB.TOTL.IN.ZS

World Bank. 2016g. Population growth (annual \%). [online] URL: http://data.worldbank.org/indicator/SP.POP.GROW

World Economic Forum. 2011. Responsible mineral development initiative.

Zinner, D., F. Peláez, and F. Torkler. 2002. Distribution and habitat of grivet monkeys (Cercopithecus aethiops aethiops) in eastern and central Eritrea. African Journal of Ecology 40:151158. http://dx.doi.org/10.1046/j.1365-2028.2002.00360.x 
Date:

\section{A 1. Questionnaire}

Village: Foyer:

Père de famille:

Nombre et âge des Femmes:

Nombre et âge des fils:

Nombre et âge des filles:

Est-ce que des parents vivent dans le foyer (âge, sex)?

1. Quel âge avez-vous?

2. Origine ethnique? $\square$ Fulbé $\square$ Malinké $\square$ Soussou $\square$ Forestiers $\square$ Étranger:

3. Ou êtes-vous né?

4. Combien d'années avez-vous vécu au village?

5. Combien de mois par an êtes-vous au village?

6. Combien de fois par mois allez-vous au marcher?

7. Combien de fois par an allez-vous en ville?

8. Travaillez-vous pendant une période de l'année dans une autre région? $\square$ Oui $\square$ Non Quel travail et région?

9. Est-ce que vous soutenez vôtre famille économiquement grâce à ce travail? $\square$ Oui $\square$ Non Si oui: $\square$ 100- 500`000 $\square$ 500'000-1'000'000 $\square$ 1'000'000-3'000'000 $\square$ Plus de 3'000'000

10. Combien d'années êtes-vous allé à l'école?

11. Quelle école? $\square$ De l'état $\square$ Coranique $\square$ Privée $\square$ Missionnaire chrétien

12. Savez-vous lire? $\square$ Oui $\square$ Non

13. Quelle est votre religion? $\square$ Musulman $\square$ Chrétien $\square$ Animiste $\square$ Autre:

14. Quelle profession exercez-vous? $\square$ Agriculteur $\square$ Éleveur $\square$ Forgeront $\square$ Commerçant $\square$ Fonctionnaire $\square$ Chasseur $\square$ Pêcheur $\square$ Religieux $\square$ Salarié $\square$ Menuisier $\square$ Maçon $\square$ Tisseur $\square$ Minier $\square$ Teinturier $\square$ Autre:

15. Quel est votre revenu mensuel?

16. Quels moyens de locomotion avez-vous?

17. Avez-vous fait des expériences avec des projets de développement/conservation?

$\square$ Oui $\square$ Non Quels projets et quand? 
FOYER SECTION CHAMPS
Date :

Heure:

1. Avez-vous des terres? $\square$ Oui $\square$ Non

Lieux (carré dans carte):

2. Cultivez-vous des champs? $\square$ Oui $\quad->\quad$ Si oui, question 3

Non $\quad \rightarrow \quad$ Si non, section jardin

3. Qui travail dans les champs?

Foyer (préciser)

Employé (préciser)

4. Pratiquez-vous une culture sur brûlis? $\square$ Oui $\square$ Non

5. Est-ce que vous épargnez certains arbres pendant le défrichement? $\quad \square$ Oui $\square$ Non

Si oui, lesquels?

6. Est-ce que vous bloquez le feu?

Oui $\square$ Non

7. Quel est votre rythme de culture et de jachère?

Culture:

Jachère:

8. Entretenez-vous des haies mortes, vives ou mixtes pour vos champs?

Mortes $\quad \square$ Vives $\quad \square$ Mixtes $\quad \square$ Pas de haies

9. À quelle distance $(\mathrm{km})$ du village vous éloignez-vous pour vos champs? 
Tableau pour les champs

\begin{tabular}{|c|c|c|c|c|c|c|}
\hline Plante & Engrais & $\begin{array}{c}\text { Grandeur } \\
\text { (largeur x longueur m) }\end{array}$ & $\begin{array}{c}\text { Lieux } \\
\text { (Carré dans carte) }\end{array}$ & $\begin{array}{c}\text { Unités récoltées } \\
\text { (Dernière récolte) }\end{array}$ & $\begin{array}{l}\text { Unités vendues } \\
\text { (Dernière récolte) }\end{array}$ & $\begin{array}{c}\text { Gain } \\
\text { (Dernière récolte) }\end{array}$ \\
\hline Riz & & & & & & \\
\hline Haricot & & & & & & \\
\hline Manioc & & & & & & \\
\hline Fonio & & & & & & \\
\hline Arachide & & & & & & \\
\hline Patate & & & & & & \\
\hline Taro & & & & & & \\
\hline Mil & & & & & & \\
\hline Autre: & & & & & & \\
\hline Autre: & & & & & & \\
\hline Autre: & & & & & & \\
\hline
\end{tabular}


FOYER SECTION JARDINS

1. Cultivez-vous des Jardins?

2. Qui travail dans les jardins?

$\square$ Foyer (préciser)
Date :

Heure:

$\square$ Oui $\quad \rightarrow \quad$ Si oui, question 2

Non $\quad \rightarrow \quad$ Si non, section arbres fruitiers

Employé (préciser)

3. Entretenez-vous des haies mortes, vives ou mixtes pour vos jardins?

$\square$ Mortes $\square$ Vives $\square$ Mixtes $\square$ Pas de haies

4. À quelle distance $(\mathrm{km})$ du village vous éloignez-vous pour vos jardins?

1. Position dans le foyer

2. Quel âge avez-vous?

3. Sexe: $\square$ Féminin $\square$ Masculin

4. De quelle origine ethnique êtes-vous ? $\square$ Fulbé $\square$ Malinké $\square$ Soussou $\square$ Forestiers $\square$ Étranger

5. Où êtes-vous né?

6. Combien d'années avez-vous vécu au village?

7. Combien de temps par an êtes-vous au village?

8. Combien de fois par mois allez-vous au marcher?

9. Combien de fois par ans allez-vous en ville?

10. Travaillez-vous pendant une période de l'année dans une autre région ? $\square$ Oui $\square$ Non

Quel travail?

11. Est-ce que vous soutenez la famille économiquement grâce à ce travail? $\square$ Oui $\square$ Non

Si oui: $\square$ 100- 500`000 $\square$ 500’000-1'000'000 $\square$ 1'000'000-3'000’000 $\square$ Plus de 3'000'000

12. Combien d'années êtes-vous allé à l'école?

13. Quelle école avez-vous fréquentée? $\square$ De l'état $\square$ Coranique $\square$ Privée $\square$ Missionnaire chrétien

14. Savez-vous lire? $\square$ Oui $\square$ Non

15. Combien d'enfants avez-vous?

16. Quelle est votre religion? $\square$ Musulman $\square$ Chrétien $\square$ Animiste $\square$ Aucune

17. Quelle profession exercez-vous ? $\square$ Agriculteur $\square$ Éleveur $\square$ Forgeront $\square$ Commerçant $\square$

Fonctionnaire $\square$ Chasseur $\square$ Pêcheur $\square$ Religieux $\square$ Salarié $\square$ Menuisier $\square$ Macon $\square$ Tisseur $\square$

Minier $\square$ Teinturier $\square$ Autre

18. Quel est votre revenu mensuel?

19. Quels moyens de locomotion avez-vous ?

20. Avez-vous fait des expériences avec des projets de développement/conservation? $\square$ Oui $\square$ Non Quels projets et quand? 
Tableau pour les jardins

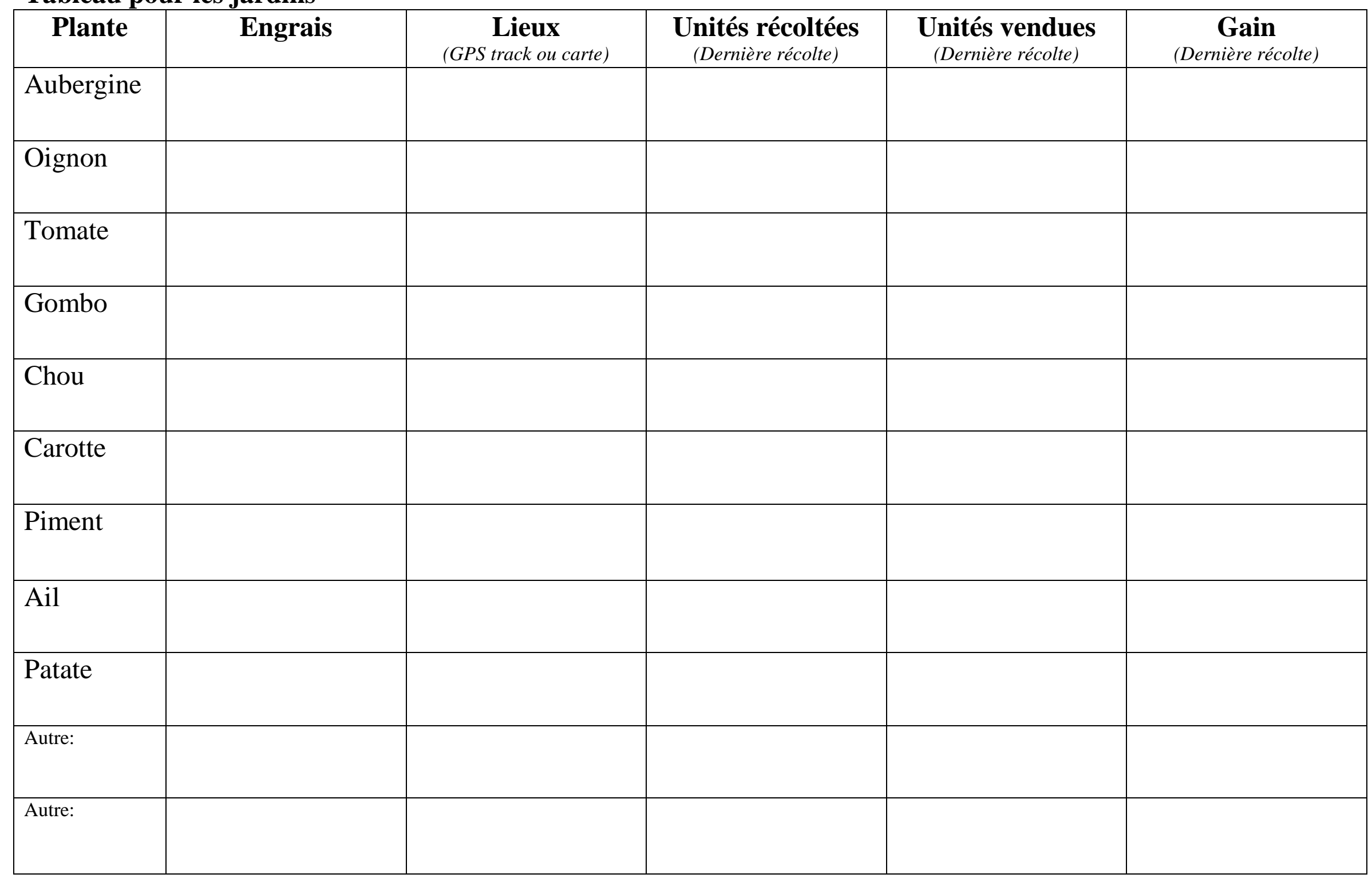


FOYER SECTION ARBRES FRUITIERS

1. Cultivez-vous des arbres fruitiers?

2. Qui s'occupe des arbres fruitiers?
Date :

\section{Heure:}

$\square$ Oui $\quad$-> Si oui, question 2

Non $\quad>\quad$ Si non, section animaux

\section{Foyer (préciser)}

Employé (préciser)

3. À quelle distance $(\mathrm{km})$ du village vous éloignez-vous pour vos arbres fruitiers?

1. Position dans le foyer

2. Quel âge avez-vous?

3. Sexe: $\square$ Féminin $\square$ Masculin

4. De quelle origine ethnique êtes-vous ? $\square$ Fulbé $\square$ Malinké $\square$ Soussou $\square$ Forestiers $\square$ Étranger

5. Où êtes-vous né?

6. Combien d'années avez-vous vécu au village?

7. Combien de temps par an êtes-vous au village?

8. Combien de fois par mois allez-vous au marcher?

9. Combien de fois par ans allez-vous en ville?

10. Travaillez-vous pendant une période de l'année dans une autre région ? $\square$ Oui $\square$ Non

Quel travail?

11. Est-ce que vous soutenez la famille économiquement grâce à ce travail? $\square$ Oui $\square$ Non

Si oui: $\square$ 100- 500`000 $\square$ 500’000-1'000'000 $\square$ 1'000'000-3'000’000 $\square$ Plus de 3'000'000

12. Combien d'années êtes-vous allé à l'école?

13. Quelle école avez-vous fréquentée? $\square$ De l'état $\square$ Coranique $\square$ Privée $\square$ Missionnaire chrétien

14. Savez-vous lire? $\square$ Oui $\square$ Non

15. Combien d'enfants avez-vous?

16. Quelle est votre religion? $\square$ Musulman $\square$ Chrétien $\square$ Animiste $\square$ Aucune

17. Quelle profession exercez-vous ? $\square$ Agriculteur $\square$ Éleveur $\square$ Forgeront $\square$ Commerçant $\square$

Fonctionnaire $\square$ Chasseur $\square$ Pêcheur $\square$ Religieux $\square$ Salarié $\square$ Menuisier $\square$ Macon $\square$ Tisseur $\square$

Minier $\square$ Teinturier $\square$ Autre

18. Quel est votre revenu mensuel?

19. Quels moyens de locomotion avez-vous?

20. Avez-vous fait des expériences avec des projets de développement/conservation? $\square$ Oui $\square$ Non

Quels projets et quand? 
Tableau pour les arbres fruitiers

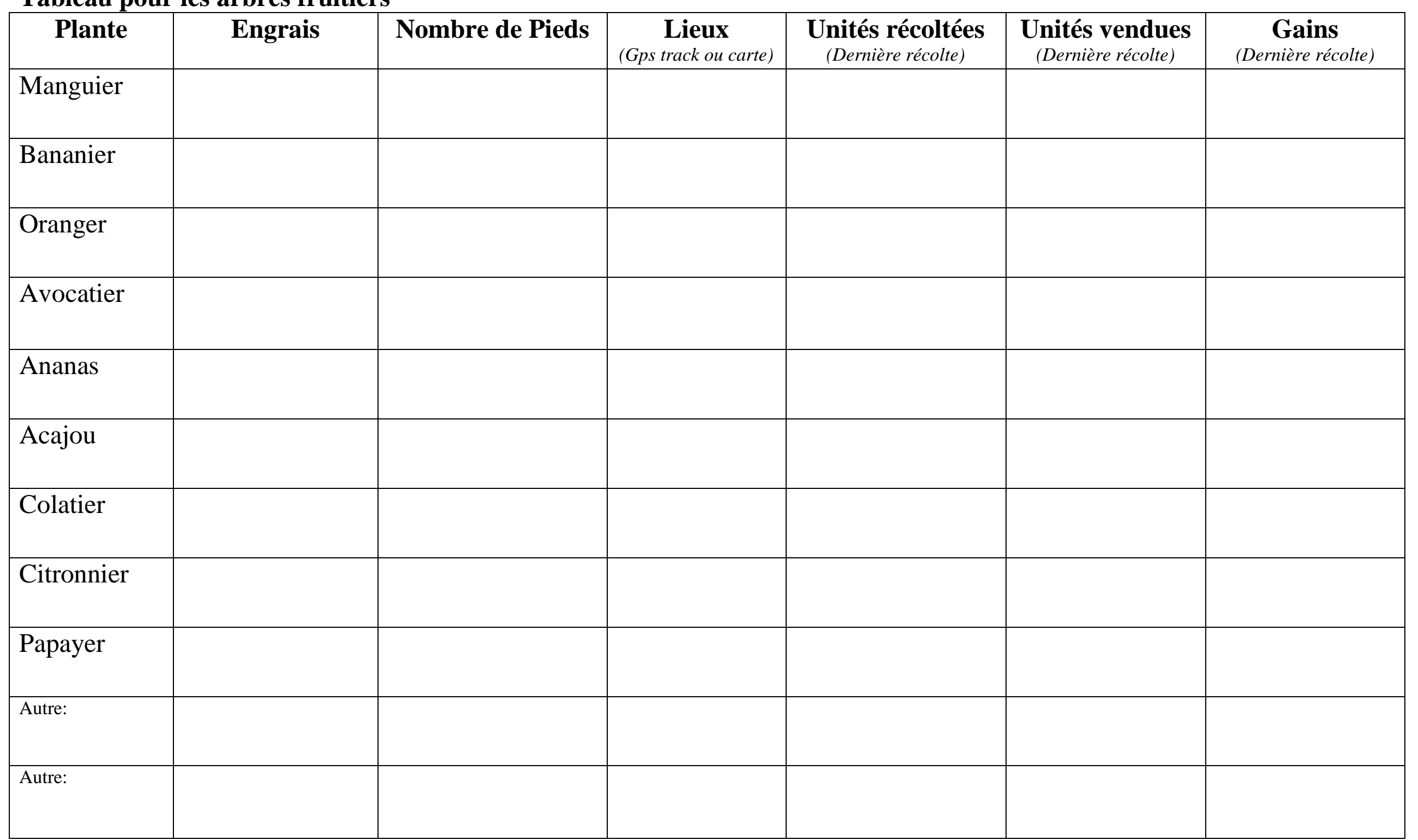




\section{FOYER SECTION ANIMAUX DOMESTIQUES}

Date :

Heure:
1. Avez-vous des animaux domestiques?
Oui $\rightarrow$ Si oui, question 2
Non -> Si non, section pêche

2. Qui s'occupe des animaux?

$\square$ Foyer (préciser)

\section{$\square$ Employé (préciser)}

3. À quelle distance $(\mathrm{km})$ du village vous éloignez-vous pour vos animaux domestiques?

1. Position dans le foyer

2. Quel âge avez-vous?

3. Sexe: $\square$ Féminin $\square$ Masculin

4. De quelle origine ethnique êtes-vous ? $\square$ Fulbé $\square$ Malinké $\square$ Soussou $\square$ Forestiers $\square$ Étranger

5. Où êtes-vous né?

6. Combien d'années avez-vous vécu au village?

7. Combien de temps par an êtes-vous au village?

8. Combien de fois par mois allez-vous au marcher?

9. Combien de fois par ans allez-vous en ville?

10. Travaillez-vous pendant une période de l'année dans une autre région ? $\square$ Oui $\square$ Non

Quel travail?

11. Est-ce que vous soutenez la famille économiquement grâce à ce travail? $\square$ Oui $\square$ Non

Si oui: $\square$ 100- 500 $000 \square$ 500'000-1'000'000 $\square$ 1'000'000-3'000'000 $\square$ Plus de 3'000'000

12. Combien d'années êtes-vous allé à l'école?

13. Quelle école avez-vous fréquentée? $\square$ De l'état $\square$ Coranique $\square$ Privée $\square$ Missionnaire chrétien

14. Savez-vous lire? $\square$ Oui $\square$ Non

15. Combien d'enfants avez-vous?

16. Quelle est votre religion? $\square$ Musulman $\square$ Chrétien $\square$ Animiste $\square$ Aucune

17. Quelle profession exercez-vous ? $\square$ Agriculteur $\square$ Éleveur $\square$ Forgeront $\square$ Commerçant $\square$

Fonctionnaire $\square$ Chasseur $\square$ Pêcheur $\square$ Religieux $\square$ Salarié $\square$ Menuisier $\square$ Macon $\square$ Tisseur $\square$

Minier $\square$ Teinturier $\square$ Autre

18. Quel est votre revenu mensuel?

19. Quels moyens de locomotion avez-vous ?

20. Avez-vous fait des expériences avec des projets de développement/conservation? $\square$ Oui $\square$ Non

Quels projets et quand? 
Tableaux pour les animaux domestiques

\begin{tabular}{|c|c|c|c|c|c|}
\hline Animal & Nombre & $\begin{array}{c}\text { Lieux } \\
\text { (Carré carte) }\end{array}$ & Utilisation & $\begin{array}{c}\text { Nombre Vendu } \\
\text { (Année dernière) }\end{array}$ & $\begin{array}{c}\text { Gain } \\
\text { (Année dernière) }\end{array}$ \\
\hline Poulet & & & & & \\
\hline Cochon & & & & & \\
\hline Cheval & & & & & \\
\hline Âne & & & & & \\
\hline Chèvre & & & & & \\
\hline Mouton & & & & & \\
\hline Escargot & & & & & \\
\hline Vache & & & & & \\
\hline Agouti & & & & & \\
\hline Pigeon & & & & & \\
\hline Ruche à miel & & & & & \\
\hline Canard & & & & & \\
\hline Autre: & & & & & \\
\hline Autre: & & & & & \\
\hline
\end{tabular}

Utilisation: Production viande; Force de travail; Production produits laitiers; Valeur; Statut; Dots; Funérailles; Culte (Sacrifice); Commerce... 


\section{FOYER SECTION PÊCHE}

Date :

Heure:
1. Est-ce que vous pêchez?
Oui $\quad \rightarrow$ Si oui, question 2
Non $\rightarrow$ Si non, section chasse

2. Combien de fois par mois pêchez-vous?

-> $\square$ Si plus de 4 fois, question 3

-> $\square$ Si moins de 5 fois, section chasse

3. Qui s'occupe de la pêche?

$\square$ Foyer (préciser)

\section{$\square$ Employé (préciser)}

4. À quelle distance $(\mathrm{km})$ du village vous éloignez-vous pour la pêche?

1. Position dans le foyer

2. Quel âge avez-vous?

3. Sexe: $\square$ Féminin $\square$ Masculin

4. De quelle origine ethnique êtes-vous ? $\square$ Fulbé $\square$ Malinké $\square$ Soussou $\square$ Forestiers $\square$ Étranger

5. Où êtes-vous né?

6. Combien d'années avez-vous vécu au village?

7. Combien de temps par an êtes-vous au village?

8. Combien de fois par mois allez-vous au marcher?

9. Combien de fois par ans allez-vous en ville?

10. Travaillez-vous pendant une période de l'année dans une autre région ? $\square$ Oui $\square$ Non

Quel travail?

11. Est-ce que vous soutenez la famille économiquement grâce à ce travail? $\square$ Oui $\square$ Non

Si oui: $\square$ 100- 500`000 $\square$ 500’000-1'000'000 $\square$ 1'000'000-3'000'000 $\square$ Plus de 3'000'000

12. Combien d'années êtes-vous allé à l'école?

13. Quelle école avez-vous fréquentée? $\square$ De l'état $\square$ Coranique $\square$ Privée $\square$ Missionnaire chrétien

14. Savez-vous lire? $\square$ Oui $\square$ Non

15. Combien d'enfants avez-vous?

16. Quelle est votre religion? $\square$ Musulman $\square$ Chrétien $\square$ Animiste $\square$ Aucune

17. Quelle profession exercez-vous ? $\square$ Agriculteur $\square$ Éleveur $\square$ Forgeront $\square$ Commerçant

Fonctionnaire $\square$ Chasseur $\square$ Pêcheur $\square$ Religieux $\square$ Salarié $\square$ Menuisier $\square$ Macon $\square$ Tisseur

Minier $\square$ Teinturier $\square$ Autre

18. Quel est votre revenu mensuel?

19. Quels moyens de locomotion avez-vous ?

20. Avez-vous fait des expériences avec des projets de développement/conservation? $\square$ Oui $\square$ Non Quels projets et quand? 
Tableau pour la pêche

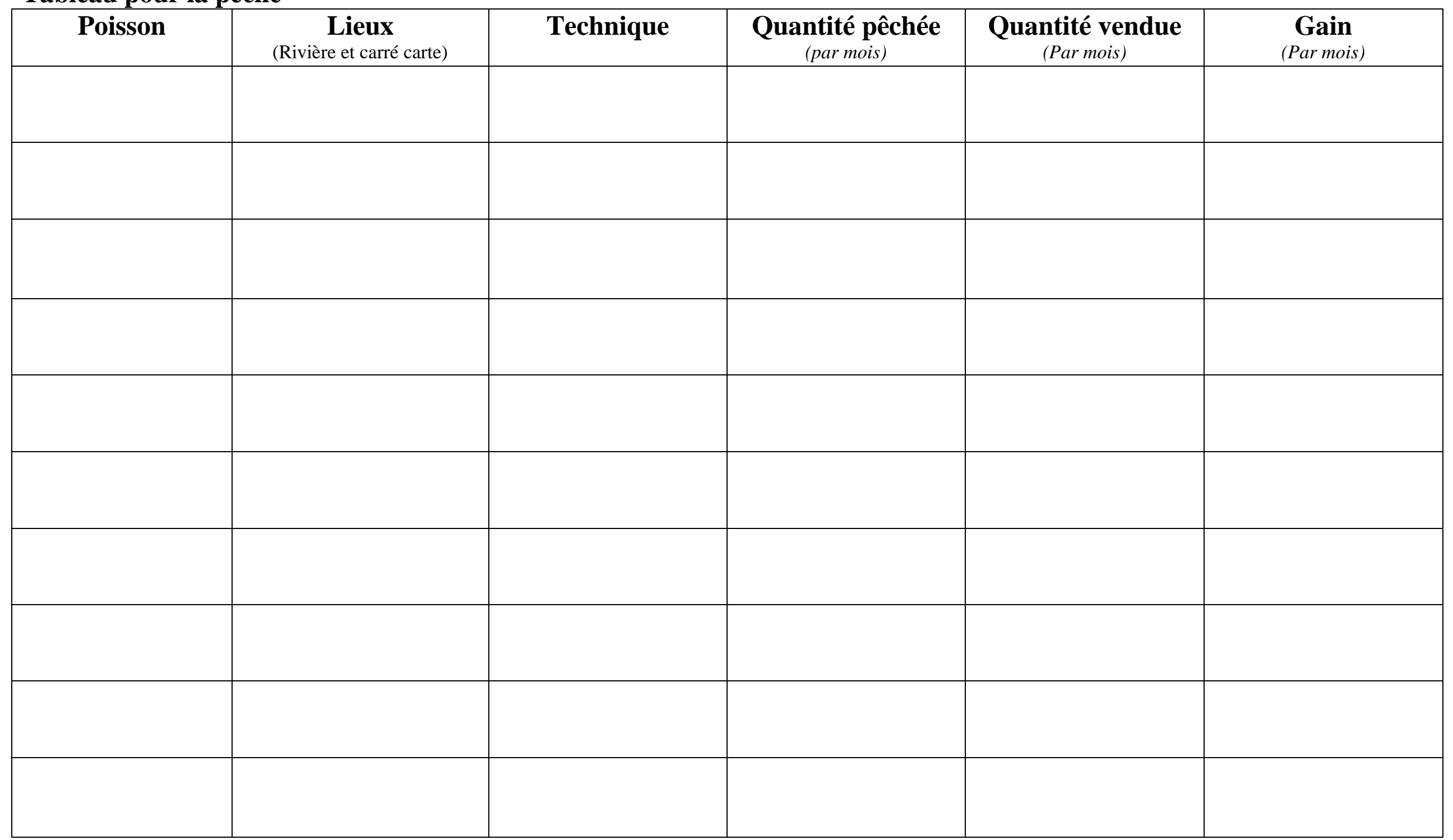

Technique: Nasse; Filet; Pêche à la ligne; Poison; Barrage; Harpon.. 
FOYER SECTION CHASSE
Date :

\section{Heure:}
1. Est-ce que vous chassez?
$\square$ Oui $\quad>$ Si oui, question 2
$\square$ Non $\quad$ > Si non, section produits de brousse

2. Combien de fois par mois chassez-vous?

-> $\square$ Si plus de 4 fois, question $3 \quad \rightarrow \square$ Si moins de 5 fois, section produits de brousse

3. Qui s'occupe de la chasse?

Foyer (préciser)

Employé (préciser)

4. Avez-vous un fusil? $\square$ Oui $\square$ Non Combiens:

5. Est-ce que vous louez un fusil? $\square$ Oui $\square$ Non Où:

6. Où vous ravitaillez-vous en munitions?

7. Quels animaux avez-vous déjà chassez (Montrer images)?

Numéro images:

8. Quels animaux ne chassez-vous jamais (Montrer images)?

Numéro images:

Pourquoi pas?

9. Est-ce que vous faites des battues ? $\square$ Oui $\square$ Non Si oui, quels animaux (Montrer images) Numéro images

10. Où vendez-vous le gibier?

11. À quelle distance $(\mathrm{km})$ du village vous éloigniez vous pour la chasse? 
Tableau pour la chasse (Jusqu'à 10 proies importantes)

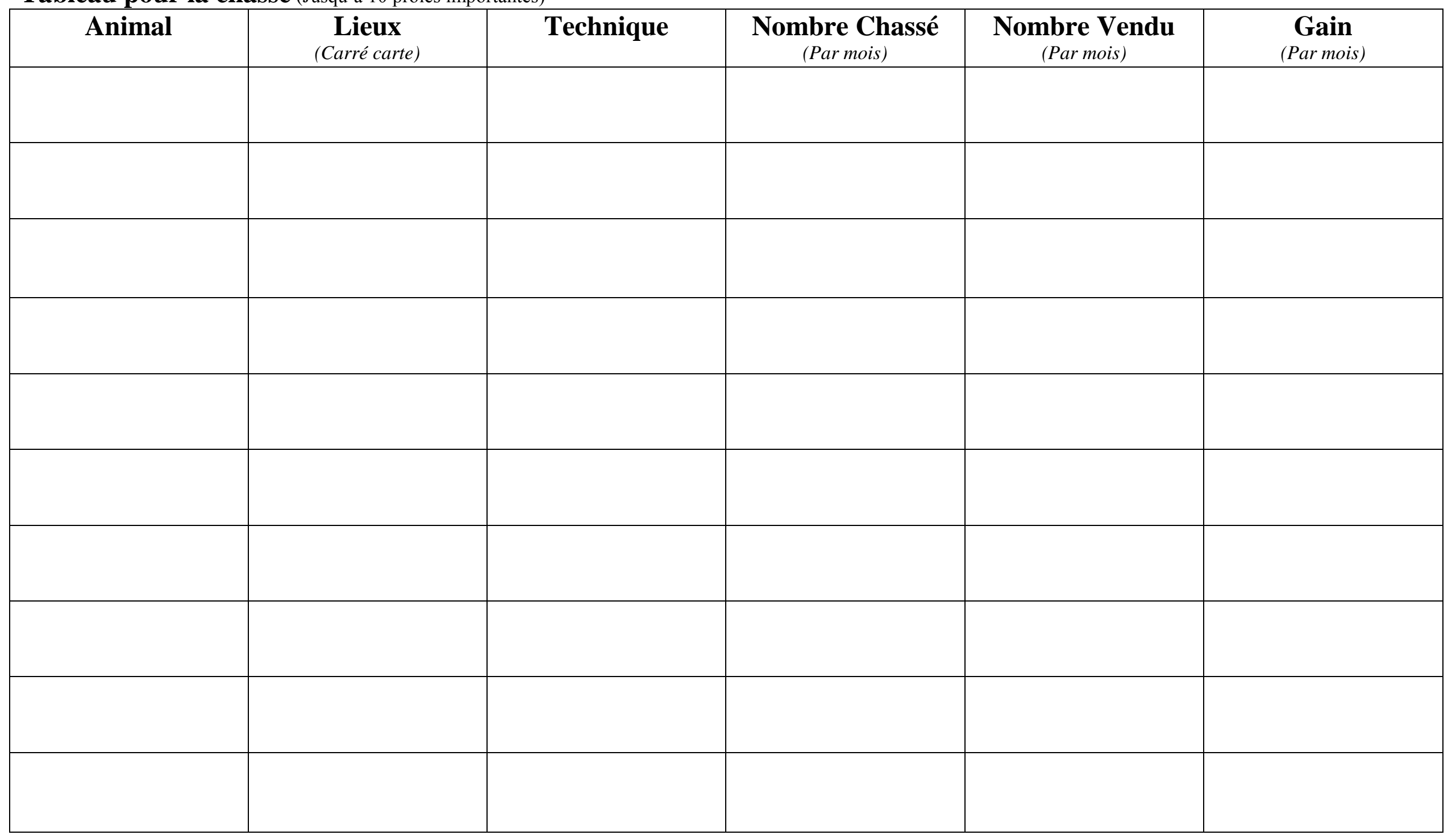

Technique: Piège; Enfume; Fusil; Arc; Chien... 


\section{FOYER SECTION PRODUITS DE LA BROUSSE Date :}

Heure:

1. Est-ce que vous utilisez des produits de la brousse? (Miel, plantes...)

$\square$ Oui -> Si oui, question 2

Non -> Si non, section soutient familial

2. Qui s'occupe de la récolte des produits de la brousse?

Foyer (préciser)

Employé (préciser)

3. À quelle distance du village $(\mathrm{km})$ vous éloignez-vous pour la récolte des produits de brousse?

1. Position dans le foyer

2. Quel âge avez-vous?

3. Sexe: $\square$ Féminin $\square$ Masculin

4. De quelle origine ethnique êtes-vous ? $\square$ Fulbé $\square$ Malinké $\square$ Soussou $\square$ Forestiers $\square$ Étranger

5. Où êtes-vous né?

6. Combien d'années avez-vous vécu au village?

7. Combien de temps par an êtes-vous au village?

8. Combien de fois par mois allez-vous au marcher?

9. Combien de fois par ans allez-vous en ville?

10. Travaillez-vous pendant une période de l'année dans une autre région ? $\square$ Oui $\square$ Non

Quel travail?

11. Est-ce que vous soutenez la famille économiquement grâce à ce travail? $\square$ Oui $\square$ Non

Si oui: $\square$ 100- 500`000 $\square$ 500'000-1'000'000 $\square$ 1'000'000-3'000'000 $\square$ Plus de 3'000'000

12. Combien d'années êtes-vous allé à l'école?

13. Quelle école avez-vous fréquentée? $\square$ De l'état $\square$ Coranique $\square$ Privée $\square$ Missionnaire chrétien

14. Savez-vous lire? $\square$ Oui $\square$ Non

15. Combien d'enfants avez-vous?

16. Quelle est votre religion? $\square$ Musulman $\square$ Chrétien $\square$ Animiste $\square$ Aucune

17. Quelle profession exercez-vous ? $\square$ Agriculteur $\square$ Éleveur $\square$ Forgeront $\square$ Commerçant $\square$

Fonctionnaire $\square$ Chasseur $\square$ Pêcheur $\square$ Religieux $\square$ Salarié $\square$ Menuisier $\square$ Macon $\square$ Tisseur $\square$

Minier $\square$ Teinturier $\square$ Autre

18. Quel est votre revenu mensuel?

19. Quels moyens de locomotion avez-vous?

20. Avez-vous fait des expériences avec des projets de développement/conservation ? $\square$ Oui $\square$ Non Quels projets et quand? 
Tableau pour produits de brousse

\begin{tabular}{|l|l|l|l|l|}
\hline \multicolumn{1}{|c|}{ Produit } & $\begin{array}{c}\text { Lieux } \\
\text { (carrécarte) }\end{array}$ & $\begin{array}{c}\text { Quantité collectée } \\
\text { (dernière saison) }\end{array}$ & $\begin{array}{c}\text { Quantitée vendue } \\
\text { (derniere saison) }\end{array}$ & $\begin{array}{c}\text { Gain } \\
\text { (dernière saison) }\end{array}$ \\
\hline Miel & & & & \\
\hline Vitelaria Paradoxa & & & & \\
\hline Tamarindus Indica & & & & \\
\hline Datrium Microcarpum & & & & \\
\hline Lannea Acida & & & & \\
\hline Parkia Biglobosa & & & & \\
\hline Xyclopia Aethiopium & & & & \\
\hline Sorendia Juglandifolia & & & & \\
\hline Landolphia Heudelotii & & & & \\
\hline Carapa Prossera & & & & \\
\hline Combretum Micranthum & & & & \\
\hline Elaeis Guineensis & & & & \\
\hline Cola Cordifolia & & & & \\
\hline Syzygium Guineense & & & & \\
\hline Vitex Doniana & & & & \\
\hline Piliostigma Thonningii & & & & \\
\hline Adonsonia Digitata & & & & \\
\hline Annona Senegalensis & & & & \\
\hline
\end{tabular}


UNIVERSITATT LEIPZIG

\begin{tabular}{|c|c|c|c|c|}
\hline Produit & $\begin{array}{c}\text { Lieux } \\
\text { (carré carte) }\end{array}$ & $\begin{array}{c}\text { Quantité collectée } \\
\text { (dernière saison) }\end{array}$ & $\begin{array}{c}\text { Quantité vendue } \\
\text { (dernière saison) }\end{array}$ & $\begin{array}{c}\text { Gain } \\
\text { (dernière saison) }\end{array}$ \\
\hline Saba & & & & \\
\hline Raphia & & & & \\
\hline Ficus & & & & \\
\hline Dialium & & & & \\
\hline Afromom & & & & \\
\hline Jetrofa & & & & \\
\hline Autre: & & & & \\
\hline Autre: & & & & \\
\hline Autre: & & & & \\
\hline Autre: & & & & \\
\hline
\end{tabular}


FOYER SECTION SOUTIEN FAMILIAL

1. Est-ce que le foyer reçoit du soutient de membre de l'extérieur?

Oui -> Question 2

Non -> Section individuelle

2. Combien de Membres soutiennent le foyer et quelle est leur fonction?
Date :

Heure:

3. À quel montant par an s'élève ce soutient?

100- 500`000 $\square$ 500'000-1'000'000 $\square$ 1'000'000-3'000'000 $\square$ Plus de 3'000'000

1. Position dans le foyer

2. Quel âge avez-vous?

3. Sexe: $\square$ Féminin $\square$ Masculin

4. De quelle origine ethnique êtes-vous ? $\square$ Fulbé $\square$ Malinké $\square$ Soussou $\square$ Forestiers $\square$ Étranger

5. Où êtes-vous né?

6. Combien d'années avez-vous vécu au village?

7. Combien de temps par an êtes-vous au village?

8. Combien de fois par mois allez-vous au marcher?

9. Combien de fois par ans allez-vous en ville?

10. Travaillez-vous pendant une période de l'année dans une autre région ? $\square$ Oui $\square$ Non Quel travail?

11. Est-ce que vous soutenez la famille économiquement grâce à ce travail? $\square$ Oui $\square$ Non

Si oui: $\square$ 100- 500`000 $\square$ 500'000-1'000'000 $\square$ 1'000'000-3'000'000 $\square$ Plus de 3'000'000

12. Combien d'années êtes-vous allé à l'école?

13. Quelle école avez-vous fréquentée? $\square$ De l'état $\square$ Coranique $\square$ Privée $\square$ Missionnaire chrétien 14. Savez-vous lire?

15. Combien d'enfants avez-vous?

16. Quelle est votre religion? $\square$ Musulman $\square$ Chrétien $\square$ Animiste $\square$ Aucune

17. Quelle profession exercez-vous ? $\square$ Agriculteur $\square$ Éleveur $\square$ Forgeront $\square$ Commerçant

Fonctionnaire $\square$ Chasseur $\square$ Pêcheur $\square$ Religieux $\square$ Salarié $\square$ Menuisier $\square$ Macon $\square$ Tisseur $\square$

Minier $\square$ Teinturier $\square$ Autre

18. Quel est votre revenu mensuel?

19. Quels moyens de locomotion avez-vous?

20. Avez-vous fait des expériences avec des projets de développement/conservation? $\square$ Oui $\square$ Non

Quels projets et quand? 
INDIVIDU SECTION CONFLITS AVEC DES ANIMAUX Date :

Nom:

Heure:

1. Avez-vous peur de certains animaux?

$\square$ Oui $\square$ Non

Lesquels?

2. Avez-vous déjà été attaqué par un animal? $\square$ Oui $\square$ Non

Lesquels?

3. Est-ce que vous vous sentez en concurrence avec des animaux pour certains produits?

Oui $\square$ Non $\quad$ Si oui: Quels produits et animaux?

4. Les animaux sauvages vous causent-ils des désagréments dans le cadre de vos activités

Oui $\square$ Non $\quad$ Si oui, précisez le genre de désagréments subis et la fréquence:

5. Les animaux sauvages causent-ils des dégâts aux cultures du village? $\square$ Oui $\square$ Non

6. A quelles cultures les animaux s'attaquent-ils? (Quels animaux/quels cultures)

7. Que feriez-vous/ font les riverains quand les animaux (leur) causent des désagréments? $\square$ Les fait fuir $\square$ Pose des pièges $\square$ Les empoisonne $\square$ Leur tire dessus $\square$ Ne fait rien Les captures

8. Organise-t-on des battues dans votre zone ? $\square$ Oui $\square$ Non

9. Que fait-on des animaux piégés lors de ces battues?

$\square$ On les tue $\square$ On les mange $\square$ On les attrape pour les vendre $\square$ On les laisse s'enfuir

10. Pensez-vous que les riverains et les animaux peuvent cohabiter sans grands dommages?

Oui $\square$ Non 
INDIVIDU SECTION TABOU

Nom:
Date :

Heure:

1. Votre religion ou vos traditions donne-t-elle des enseignements pour l'attitude à avoir visà-vis des animaux sauvages en général? $\square$ Oui $\square$ Non

Des chimpanzés? $\quad \square$ Oui $\square$ Non

Si oui, précisez

2. Ces enseignements sont-ils toujours respectés ? $\square$ Oui $\square$ Non

3. Quelle est la loi concernant l'utilisation des animaux sauvages? (différents animaux)

4. Pensez-vous que les animaux devraient être protégés par la loi Guinéenne?

\section{Oui $\square$ Non}

Pourquoi?

5. Pensez-vous que les lois qui protègent les animaux sont efficacement appliquées ?

Oui $\square$ Non

6. Connaissez-vous des gens qui ont tué des chimpanzés?

Oui $\square$ Non

7. Connaissez-vous des gens qui ont été punis par la loi pour avoir tué des chimpanzés ?

Oui $\square$ Non 
Date

\section{Impressions sur les réponses données}

1. Est-ce que les personnes questionnées ont réfléchi avant de répondre?

Très $\square$ plutôt $\square$ ni I'un ni l’autre $\square$ plutôt pas $\square$ pas du tout

2. Est-ce que les personnes étaient attentives?

Très $\square$ plutôt $\square$ ni l`un ni l`autre $\square$ plutôt pas $\square$ pas du tout

3. Est-ce que les personnes étaient influencées dans leurs réponses par d'autres?

$\square$ Très $\square$ plutôt $\square$ ni l`un ni l`autre $\square$ plutôt pas $\square$ pas du tout

4. Est-ce que les personnes vous paraissaient sincères?

Très $\square$ plutôt $\square$ ni l`un ni l`autre $\square$ plutôt pas $\square$ pas du tout

5. Est-ce que les réponses vous paraissent probables?

Très $\square$ plutôt $\square$ ni I’un ni l’autre $\square$ plutôt pas $\square$ pas du tout 
A2.1 Correlations among predictor and control variables for the data on duiker, bushbuck, African civet, porcupine, hare, wart hog, jackal, common genet, Guinea baboon and patas monkey.

\begin{tabular}{|c|c|c|c|c|c|c|c|c|c|c|}
\hline & $\begin{array}{l}\text { Market } \\
\text { integration }\end{array}$ & $\begin{array}{l}\text { Hunting } \\
\text { pressure }\end{array}$ & $\begin{array}{l}\text { Population } \\
\text { density }\end{array}$ & $\begin{array}{l}\text { Distance } \\
\text { nearest } \\
\text { road } \\
\end{array}$ & $\begin{array}{l}\text { Fish } \\
\text { provision }\end{array}$ & $\begin{array}{l}\text { Taboo } \\
\text { influence }\end{array}$ & $\begin{array}{l}\text { Share } \\
\text { classified } \\
\text { forest } \\
\end{array}$ & $\begin{array}{l}\text { Distance } \\
\text { nearest } \\
\text { field }\end{array}$ & NDVI & $\begin{array}{l}\text { Distance } \\
\text { nearest } \\
\text { river }\end{array}$ \\
\hline $\begin{array}{l}\text { Market } \\
\text { integration }\end{array}$ & 1 & 0.781 & 0.85 & 0.015 & 0.933 & 0.249 & -0.236 & -0.386 & -0.066 & -0.124 \\
\hline $\begin{array}{l}\text { Hunting } \\
\text { pressure }\end{array}$ & 0.781 & 1 & 0.979 & -0.128 & 0.917 & 0.247 & -0.056 & -0.414 & -0.026 & -0.168 \\
\hline $\begin{array}{l}\text { Population } \\
\text { density }\end{array}$ & 0.85 & 0.979 & 1 & -0.126 & 0.953 & 0.257 & -0.105 & -0.407 & -0.034 & -0.154 \\
\hline $\begin{array}{l}\text { Distance } \\
\text { nearest road }\end{array}$ & 0.015 & -0.128 & -0.126 & 1 & -0.012 & -0.016 & 0.308 & 0.541 & 0.204 & 0.171 \\
\hline $\begin{array}{l}\text { Fish } \\
\text { provision }\end{array}$ & 0.933 & 0.917 & 0.953 & -0.012 & 1 & 0.261 & -0.151 & -0.374 & -0.057 & -0.177 \\
\hline $\begin{array}{l}\text { Taboo } \\
\text { influence }\end{array}$ & 0.249 & 0.247 & 0.257 & -0.016 & 0.261 & 1 & -0.04 & -0.103 & 0.006 & -0.039 \\
\hline NDVI & -0.066 & -0.026 & -0.034 & 0.204 & -0.057 & 0.006 & 0.127 & 0.11 & 1 & 0.133 \\
\hline $\begin{array}{l}\text { Distance } \\
\text { nearest river }\end{array}$ & -0.124 & -0.168 & -0.154 & 0.171 & -0.177 & -0.039 & 0.074 & 0.327 & 0.133 & 1 \\
\hline
\end{tabular}

\section{A2.2 Correlations among predictor and control variables for the data on chimpanzee.}

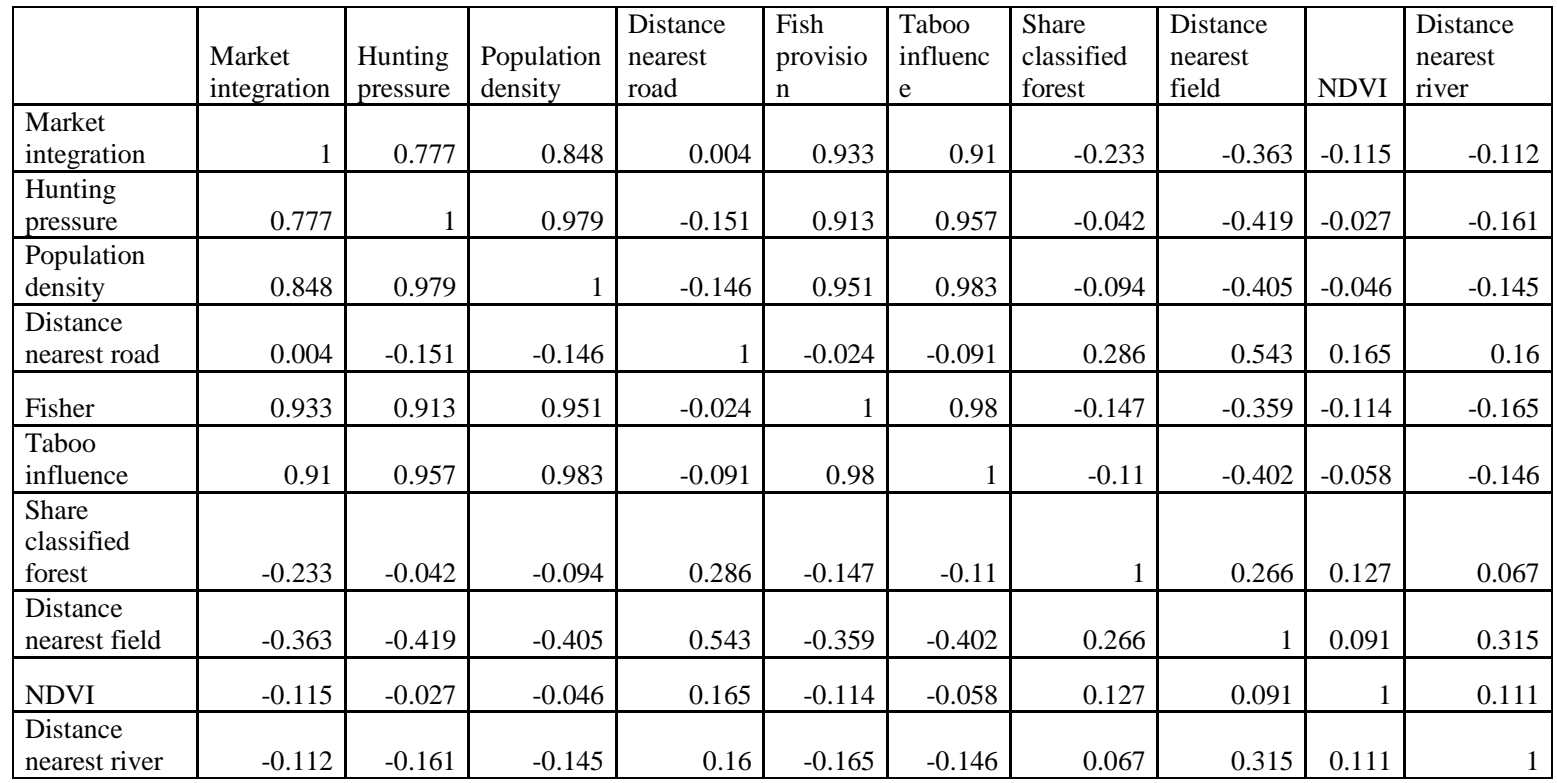


A3.1 Model formulas of all mixed effects Poisson regression models in the model set used for the model selection analysis on mixed species abundance in $\mathrm{R}$

\begin{tabular}{|c|c|}
\hline 1 & $\begin{array}{l}\text { abundance } \sim \text { Z.ndvi+Z.sqrt.dist.field+Z.sqrt.dist.river+z.sqrt.dist.roads+z.percent.protected+ } \\
\text { ac.term+offset(log(transect.length) })+ \\
(1+\text { ac.term||transect.ID })+(1+\text { ac.term||species })\end{array}$ \\
\hline 2 & $\begin{array}{l}\text { abundance } \text { Z.sqrt.market+z.ndvi+z.sqrt.dist.field+z.sqrt.dist.river+z.sqrt.dist.roads+ } \\
\text { z.percent.protected+ac.term+offset(log(transect.length))+ } \\
(1+\text { ac.term||transect.ID })+(1+\text { ac.term||species })\end{array}$ \\
\hline 3 & $\begin{array}{l}\text { abundance } \text { z.hunter+z.ndvi+z.sqrt.dist.field+z.sqrt.dist.river+z.sqrt.dist.roads+ } \\
\text { z.percent.protected+ac.term+offset(log(transect.length))+ } \\
(1+\text { ac.term||transect.ID })+(1+\text { ac.term||species })\end{array}$ \\
\hline 4 & $\begin{array}{l}\text { abundance } \sim \text { z.fisher+z.ndvi+z.sqrt.dist.field+z.sqrt.dist.river+z.sqrt.dist.roads+ } \\
\text { z.percent.protected+ac.term+offset(log(transect.length) })+ \\
(1+\text { ac.term||transect.ID })+(1+\text { ac.term||species })\end{array}$ \\
\hline 5 & $\begin{array}{l}\text { abundance } \sim \text { z.taboo+z.ndvi+z.sqrt.dist.field+z.sqrt.dist.river+z.sqrt.dist.roads+ } \\
\text { z.percent.protected+ac.term+offset(log(transect.length) })+ \\
(1+\text { ac.term||transect.ID })+(1+\text { ac.term||species })\end{array}$ \\
\hline 6 & $\begin{array}{l}\text { abundance z.tr.pop.size+z.ndvi+Z.sqrt.dist.field+z.sqrt.dist.river+Z.sqrt.dist.roads+ } \\
\text { z.percent.protected+ac.term+offset(log(transect.length))+ } \\
(1+\text { ac.term||transect.ID })+(1+\text { ac.term||species })\end{array}$ \\
\hline 7 & $\begin{array}{l}\text { abundance } \sim \text { z.fisher+z.taboo+z.ndvi+z.sqrt.dist.field+z.sqrt.dist.river+z.sqrt.dist.roads+ } \\
\text { z.percent.protected+ac.term+offset(log(transect.length))+ } \\
(1+\text { ac.term } \| \text { |transect.ID })+(1+\text { ac.term } \| \text { species })\end{array}$ \\
\hline 8 & $\begin{array}{l}\text { abundance } \sim \text { z.hunter+z.sqrt.market+z.ndvi+z.sqrt.dist.field+z.sqrt.dist.river+Z.sqrt.dist.roads+ } \\
\text { z.percent.protected+ac.term+offset(log(transect.length) })+ \\
(1+\text { ac.term||transect.ID })+(1+\text { ac.term||species })\end{array}$ \\
\hline 9 & $\begin{array}{l}\text { abundance } \sim \text { z.hunter+z.taboo+z.ndvi+z.sqrt.dist.field+z.sqrt.dist.river+z.sqrt.dist.roads+ } \\
\text { z.percent.protected+ac.term+offset(log(transect.length) })+ \\
(1+\text { ac.term||transect.ID })+(1+\text { ac.term } \mid \text { species })\end{array}$ \\
\hline 10 & $\begin{array}{l}\text { abundance } \sim \text { z.sqrt.market+z.taboo+z.ndvi+z.sqrt.dist.field+z.sqrt.dist.river+z.sqrt.dist.roads+ } \\
\text { z.percent.protected+ac.term+offset(log(transect.length) })+ \\
(1+\text { ac.term } \| \text { transect.ID })+(1+\text { ac.term } \| \text { species })\end{array}$ \\
\hline 11 & $\begin{array}{l}\text { abundance } \sim \text { z.sqrt.market+z.tr.pop.size+z.ndvi+z.sqrt.dist.field+z.sqrt.dist.river+ } \\
\text { z.sqrt.dist.roads+z.percent.protected+ac.term+offset(log(transect.length))+ } \\
(1+\text { ac.term||transect.ID })+(1+\text { ac.term||species })\end{array}$ \\
\hline 12 & $\begin{array}{l}\text { abundance } \sim \text { z.taboo+z.tr.pop.size+z.ndvi+z.sqrt.dist.field+z.sqrt.dist.river+z.sqrt.dist.roads+ } \\
\text { z.percent.protected+ac.term+offset(log(transect.length })+ \\
(1+\text { ac.term||transect.ID })+(1+\text { ac.term } \mid \text { species })\end{array}$ \\
\hline 13 & $\begin{array}{l}\text { abundance } \sim \text {.hunter+z.sqrt.market+z.taboo+z.ndvi+z.sqrt.dist.field+z.sqrt.dist.river+ } \\
\text { z.sqrt.dist.roads+z.percent.protected+ } \\
\text { ac.term+offset(log(transect.length))+ } \\
(1+\text { ac.term } \| \text { transect.ID })+(1+\text { ac.term||species }) \\
\end{array}$ \\
\hline 14 & $\begin{array}{l}\text { abundance } \sim \text { z.sqrt.market+z.taboo+z.tr.pop.size+z.ndvi+z.sqrt.dist.field+z.sqrt.dist.river+ } \\
\text { z.sqrt.dist.roads+z.percent.protected+ } \\
\text { ac.term+offset(log(transect.length))+ } \\
(1+\text { ac.term } \| \text { transect.ID })+(1+\text { ac.term } \| \text { species })\end{array}$ \\
\hline 15 & $\begin{array}{l}\text { abundance } \text { z.ndvi+z.sqrt.dist.field+z.sqrt.dist.river+z.sqrt.dist.roads+z.percent.protected+ } \\
\text { ac.term+offset(log(transect.length))+ } \\
\text { (1+ac.term||transect.ID)+(1+z.ndvi+z.sqrt.dist.field+z.sqrt.dist.river+z.sqrt.dist.roads+ } \\
\text { z.percent.protected+ac.term||species) }\end{array}$ \\
\hline 16 & $\begin{array}{l}\text { abundance } \sim \text { z.sqrt.market+Z.ndvi+z.sqrt.dist.field+z.sqrt.dist.river+Z.sqrt.dist.roads+ } \\
\text { z.percent.protected+ } \\
\text { ac.term+offset(log(transect.length))+ } \\
(1+\text { ac.term||transect.ID)+(1+z.sqrt.market+z.ndvi+z.sqrt.dist.field+z.sqrt.dist.river+ }\end{array}$ \\
\hline
\end{tabular}




\begin{tabular}{|c|c|}
\hline & z.sqrt.dist.roads+z.percent.protected+ac.term||species) \\
\hline 17 & $\begin{array}{l}\text { abundance } \sim \text { z.hunter+Z.ndvi+z.sqrt.dist.field+z.sqrt.dist.river+z.sqrt.dist.roads+ } \\
\text { z.percent.protected+ac.term+offset(log(transect.length))+ } \\
\text { (1+ac.term||transect.ID)+(1+z.hunter+Z.ndvi+z.sqrt.dist.field+z.sqrt.dist.river+z.sqrt.dist.roads+ } \\
\text { z.percent.protected+ac.term||species) }\end{array}$ \\
\hline 18 & $\begin{array}{l}\text { abundance } \sim \text { z.fisher+z.ndvi+z.sqrt.dist.field+Z.sqrt.dist.river+Z.sqrt.dist.roads+ } \\
\text { z.percent.protected+ac.term+offset(log(transect.length))+ } \\
\text { (1+ac.term||transect.ID)+(1+z.fisher+z.ndvi+z.sqrt.dist.field+z.sqrt.dist.river+Z.sqrt.dist.roads+ } \\
\text { z.percent.protected+ac.term||species) }\end{array}$ \\
\hline 19 & $\begin{array}{l}\text { abundance } \sim \text { z.taboo+z.ndvi+z.sqrt.dist.field+z.sqrt.dist.river+z.sqrt.dist.roads+ } \\
\text { z.percent.protected+ac.term+offset(log(transect.length))+ } \\
\text { (1+ac.term||transect.ID)+(1+z.taboo+z.ndvi+z.sqrt.dist.field+z.sqrt.dist.river+z.sqrt.dist.roads+ } \\
\text { z.percent.protected+ac.term||species) }\end{array}$ \\
\hline 20 & $\begin{array}{l}\text { abundance } \text { Z.tr.pop.size+z.ndvi+z.sqrt.dist.field+z.sqrt.dist.river+z.sqrt.dist.roads+ } \\
\text { z.percent.protected+ac.term+offset(log(transect.length))+ } \\
\text { (1+ac.term||transect.ID)+(1+z.tr.pop.size+Z.ndvi+z.sqrt.dist.field+z.sqrt.dist.river+ } \\
\text { z.sqrt.dist.roads+z.percent.protected+ac.term||species) }\end{array}$ \\
\hline 21 & $\begin{array}{l}\text { abundance } \sim \text {.fisher+z.taboo+z.ndvi+z.sqrt.dist.field+z.sqrt.dist.river+z.sqrt.dist.roads+ } \\
\text { z.percent.protected+ac.term+offset(log(transect.length))+ } \\
\text { (1+ac.term||transect.ID)+(1+z.fisher+z.taboo+z.ndvi+z.sqrt.dist.field+z.sqrt.dist.river+ } \\
\text { z.sqrt.dist.roads+z.percent.protected+ac.term||species) }\end{array}$ \\
\hline 22 & $\begin{array}{l}\text { abundance } \sim \text {.hunter+z.sqrt.market+z.ndvi+z.sqrt.dist.field+z.sqrt.dist.river+z.sqrt.dist.roads+ } \\
\text { z.percent.protected+ac.term+offset(log(transect.length))+ } \\
\text { (1+ac.term||transect.ID)+(1+z.hunter+z.sqrt.market+z.ndvi+z.sqrt.dist.field+z.sqrt.dist.river+ } \\
\text { z.sqrt.dist.roads+z.percent.protected+ac.term||species) }\end{array}$ \\
\hline 23 & $\begin{array}{l}\text { abundance } \sim \text {.hunter+z.taboo+z.ndvi+z.sqrt.dist.field+z.sqrt.dist.river+z.sqrt.dist.roads+ } \\
\text { z.percent.protected+ac.term+offset(log(transect.length))+ } \\
\text { (1+ac.term||transect.ID)+(1+z.hunter+z.taboo+z.ndvi+z.sqrt.dist.field+z.sqrt.dist.river+ } \\
\text { z.sqrt.dist.roads+z.percent.protected+ac.term||species) }\end{array}$ \\
\hline 24 & $\begin{array}{l}\text { abundance } \sim \text { z.sqrt.market+z.taboo+z.ndvi+Z.sqrt.dist.field+z.sqrt.dist.river+Z.sqrt.dist.roads+ } \\
\text { z.percent.protected+ac.term+offset(log(transect.length))+ } \\
\text { (1+ac.term||transect.ID)+(1+z.sqrt.market+z.taboo+z.ndvi+z.sqrt.dist.field+Z.sqrt.dist.river+ } \\
\text { z.sqrt.dist.roads+z.percent.protected+ac.term||species) }\end{array}$ \\
\hline 25 & $\begin{array}{l}\text { abundance } \sim \text { z.sqrt.market+z.tr.pop.size+z.ndvi+z.sqrt.dist.field+z.sqrt.dist.river+ } \\
\text { z.sqrt.dist.roads+z.percent.protected+ac.term+offset(log(transect.length))+ } \\
\text { (1+ac.term||transect.ID)+(1+z.sqrt.market+z.tr.pop.size+z.ndvi+z.sqrt.dist.field+z.sqrt.dist.river+ } \\
\text { z.sqrt.dist.roads+Z.percent.protected+ac.term||species) }\end{array}$ \\
\hline 26 & $\begin{array}{l}\text { abundance } \sim \text { z.taboo+z.tr.pop.size+z.ndvi+z.sqrt.dist.field+z.sqrt.dist.river+z.sqrt.dist.roads+ } \\
\text { z.percent.protected+ac.term+offset(log(transect.length))+ } \\
\text { (1+ac.term||transect.ID)+(1+z.taboo+z.tr.pop.size+z.ndvi+z.sqrt.dist.field+z.sqrt.dist.river+ } \\
\text { z.sqrt.dist.roads+z.percent.protected+ac.term||species) }\end{array}$ \\
\hline 27 & $\begin{array}{l}\text { abundance } \sim \text { z.hunter+z.sqrt.market+z.taboo+z.ndvi+z.sqrt.dist.field+z.sqrt.dist.river+ } \\
\text { z.sqrt.dist.roads+z.percent.protected+ac.term+offset(log(transect.length))+ } \\
\text { (1+ac.term||transect.ID)+(1+z.hunter+z.sqrt.market+z.taboo+z.ndvi+z.sqrt.dist.field+ } \\
\text { z.sqrt.dist.river+z.sqrt.dist.roads+z.percent.protected+ac.term||species) }\end{array}$ \\
\hline 28 & $\begin{array}{l}\text { abundance } \text { Z.sqrt.market+z.taboo+z.tr.pop.size+z.ndvi+z.sqrt.dist.field+z.sqrt.dist.river+ } \\
\text { z.sqrt.dist.roads+z.percent.protected+ac.term+offset(log(transect.length))+ } \\
\text { (1+ac.term||transect.ID)+(1+z.sqrt.market+z.taboo+z.tr.pop.size+z.ndvi+z.sqrt.dist.field+ } \\
\text { z.sqrt.dist.river+z.sqrt.dist.roads+z.percent.protected+ac.term||species) }\end{array}$ \\
\hline 29 & abundance $\sim$ ac.term+offset $(\log ($ transect.length $))+(1+$ ac.term||transect.ID $)+(1+$ ac.term $\mid$ species $)$ \\
\hline 30 & $\begin{array}{l}\text { abundance } \text { Z.sqrt.market+ } \\
\text { ac.term+offset(log(transect.length) })+ \\
(1+\text { ac.term } \| \text { transect.ID })+(1+\text { ac.term } \| \text { species })\end{array}$ \\
\hline 31 & $\begin{array}{l}\text { abundance } \sim \text { z.hunter+ } \\
\text { ac.term+offset(log(transect.length })+\end{array}$ \\
\hline
\end{tabular}




\begin{tabular}{|c|c|}
\hline & $(1+$ ac.term||transect.ID)+(1+ac.term||species $)$ \\
\hline 32 & $\begin{array}{l}\text { abundance } \text { Z.fisher+ } \\
\text { ac.term+offset(log(transect.length) })+ \\
(1+\text { ac.term } \| \text { transect.ID })+(1+\text { ac.term } \| \text { species }) \\
\end{array}$ \\
\hline 33 & $\begin{array}{l}\text { abundance } \sim \text { Z.taboo+ } \\
\text { ac.term+offset(log(transect.length })+ \\
(1+\text { ac.term } \| \text { transect.ID })+(1+\text { ac.term } \| \text { species })\end{array}$ \\
\hline 34 & $\begin{array}{l}\text { abundance } \sim . t r . p o p . s i z e+ \\
\text { ac.term+offset(log(transect.length) })+ \\
(1+\text { ac.term||transect.ID })+(1+\text { ac.term||species })\end{array}$ \\
\hline 35 & $\begin{array}{l}\text { abundance } \sim \text { z.fisher+Z.taboo+ } \\
\text { ac.term+offset(log(transect.length) })+ \\
(1+\text { ac.term||transect.ID })+(1+\text { ac.term||species })\end{array}$ \\
\hline 36 & $\begin{array}{l}\text { abundance } \sim \text { z.hunter+z.sqrt.market+ } \\
\text { ac.term+offset(log(transect.length) })+ \\
(1+\text { ac.term||transect.ID })+(1+\text { ac.term ||species })\end{array}$ \\
\hline 37 & $\begin{array}{l}\text { abundance } \sim \text { Z.hunter+z.taboo+ } \\
\text { ac.term+offset(log(transect.length })+ \\
(1+\text { ac.term||transect.ID })+(1+\text { ac.term } \| \text { species })\end{array}$ \\
\hline 38 & $\begin{array}{l}\text { abundance } \sim \text { Z.sqrt.market+z.taboo+ } \\
\text { ac.term+offset(log(transect.length) })+ \\
(1+\text { ac.term } \| \text { transect.ID })+(1+\text { ac.term } \| \text { species })\end{array}$ \\
\hline 39 & $\begin{array}{l}\text { abundance } \sim \text { Z.sqrt.market+z.tr.pop.size+ } \\
\text { ac.term+offset(log(transect.length) })+ \\
(1+\text { ac.term ||transect.ID })+(1+\text { ac.term||species })\end{array}$ \\
\hline 40 & $\begin{array}{l}\text { abundance Z.taboo+z.tr.pop.size+ } \\
\text { ac.term+offset(log(transect.length) })+ \\
(1+\text { ac.term } \| \text { |ransect.ID })+(1+\text { ac.term } \| \text { species })\end{array}$ \\
\hline 41 & $\begin{array}{l}\text { abundance } \sim \text { z.hunter+z.sqrt.market+z.taboo+ } \\
\text { ac.term+offset(log(transect.length))+ } \\
(1+\text { ac.term||transect.ID })+(1+\text { ac.term } \| \text { species })\end{array}$ \\
\hline 42 & $\begin{array}{l}\text { abundance } \text { Z.sqrt.market+z.taboo+z.tr.pop.size+ } \\
\text { ac.term+offset(log(transect.length) })+ \\
(1+\text { ac.term } \| \text { transect.ID })+(1+\text { ac.term } \| \text { species })\end{array}$ \\
\hline 43 & $\begin{array}{l}\text { abundance } \text { Z.sqrt.market+ } \\
\text { ac.term+offset(log(transect.length) })+ \\
(1+\text { ac.term } \| \text { transect.ID })+(1+\text { z.sqrt.market+ac.term||species })\end{array}$ \\
\hline 44 & $\begin{array}{l}\text { abundance } \text { z.hunter+ } \\
\text { ac.term+offset(log(transect.length })+ \\
(1+\text { ac.term } \mid \text { |transect.ID })+(1+\text { z.hunter+ac.term ||species })\end{array}$ \\
\hline 45 & $\begin{array}{l}\text { abundance } \sim \text { z.fisher+ } \\
\text { ac.term+offset(log(transect.length) })+ \\
(1+\text { ac.term } \| \operatorname{transect.ID})+(1+\text { z.fisher+ac.term } \| \text { species })\end{array}$ \\
\hline 46 & $\begin{array}{l}\text { abundance } \sim \text { Z.taboo+ } \\
\text { ac.term+offset(log(transect.length) })+ \\
(1+\text { ac.term } \| \text { transect.ID })+(1+\text { z.taboo+ac.term } \| \text { species })\end{array}$ \\
\hline 47 & $\begin{array}{l}\text { abundance } \sim \text { Z.tr.pop.size+ } \\
\text { ac.term+offset(log(transect.length) })+ \\
(1+\text { ac.term||transect.ID })+(1+\text { z.tr.pop.size+ac.term } \| \text { species })\end{array}$ \\
\hline 48 & $\begin{array}{l}\text { abundance } \sim \text { Z.fisher+z.taboo+ } \\
\text { ac.term+offset(log(transect.length) })+ \\
(1+\text { ac.term||transect.ID)+(1+z.fisher+z.taboo+ac.term||species })\end{array}$ \\
\hline 49 & $\begin{array}{l}\text { abundance } \text { z.hunter+z.sqrt.market+ } \\
\text { ac.term+offset(log(transect.length) })+ \\
(1+\text { ac.term } \| \text { |transect.ID })+(1+\text { z.hunter+z.sqrt.market+ac.term||species })\end{array}$ \\
\hline
\end{tabular}




\begin{tabular}{|c|c|}
\hline 50 & $\begin{array}{l}\text { abundance } \text { Z.hunter+z.taboo+ } \\
\text { ac.term+offset(log(transect.length))+ } \\
(1+\text { ac.term||transect.ID })+(1+\text { z.hunter+z.taboo+ac.term\|species })\end{array}$ \\
\hline 51 & $\begin{array}{l}\text { abundance } \sim \text { Z.sqrt.market+z.taboo+ } \\
\text { ac.term+offset(log(transect.length))+ } \\
(1+\text { ac.term ||transect.ID })+(1+\text { z.sqrt.market+z.taboo+ac.term\|species })\end{array}$ \\
\hline 52 & $\begin{array}{l}\text { abundance } \text { z.sqrt.market+z.tr.pop.size+ } \\
\text { ac.term+offset(log(transect.length) })+ \\
(1+\text { ac.term||transect.ID })+(1+\text { z.sqrt.market+z.tr.pop.size+ac.term||species })\end{array}$ \\
\hline 53 & $\begin{array}{l}\text { abundance } \text { z.taboo+z.tr.pop.size+ } \\
\text { ac.term+offset(log(transect.length) })+ \\
(1+\text { ac.term } \| \text { transect.ID })+(1+\text { z.taboo+z.tr.pop.size+ac.term||species })\end{array}$ \\
\hline 54 & $\begin{array}{l}\text { abundance } \sim \text { Z.hunter+z.sqrt.market+z.taboo+ } \\
\text { ac.term+offset(log(transect.length) })+ \\
(1+\text { ac.term ||transect.ID })+(1+\text { z.hunter+z.sqrt.market+z.taboo+ac.term||species })\end{array}$ \\
\hline 55 & $\begin{array}{l}\text { abundance } \sim \text { z.sqrt.market+z.taboo+z.tr.pop.size+ } \\
\text { ac.term+offset(log(transect.length))+ } \\
(1+\text { ac.term } \| \text { transect.ID })+(1+\text { z.sqrt.market+z.taboo+z.tr.pop.size+ac.term } \| \text { species })\end{array}$ \\
\hline
\end{tabular}

A3.2 Model formulas of all zero inflated negative binomial regression models in the model set used for the model selection analysis on chimpanzee abundance in $\mathrm{R}$.

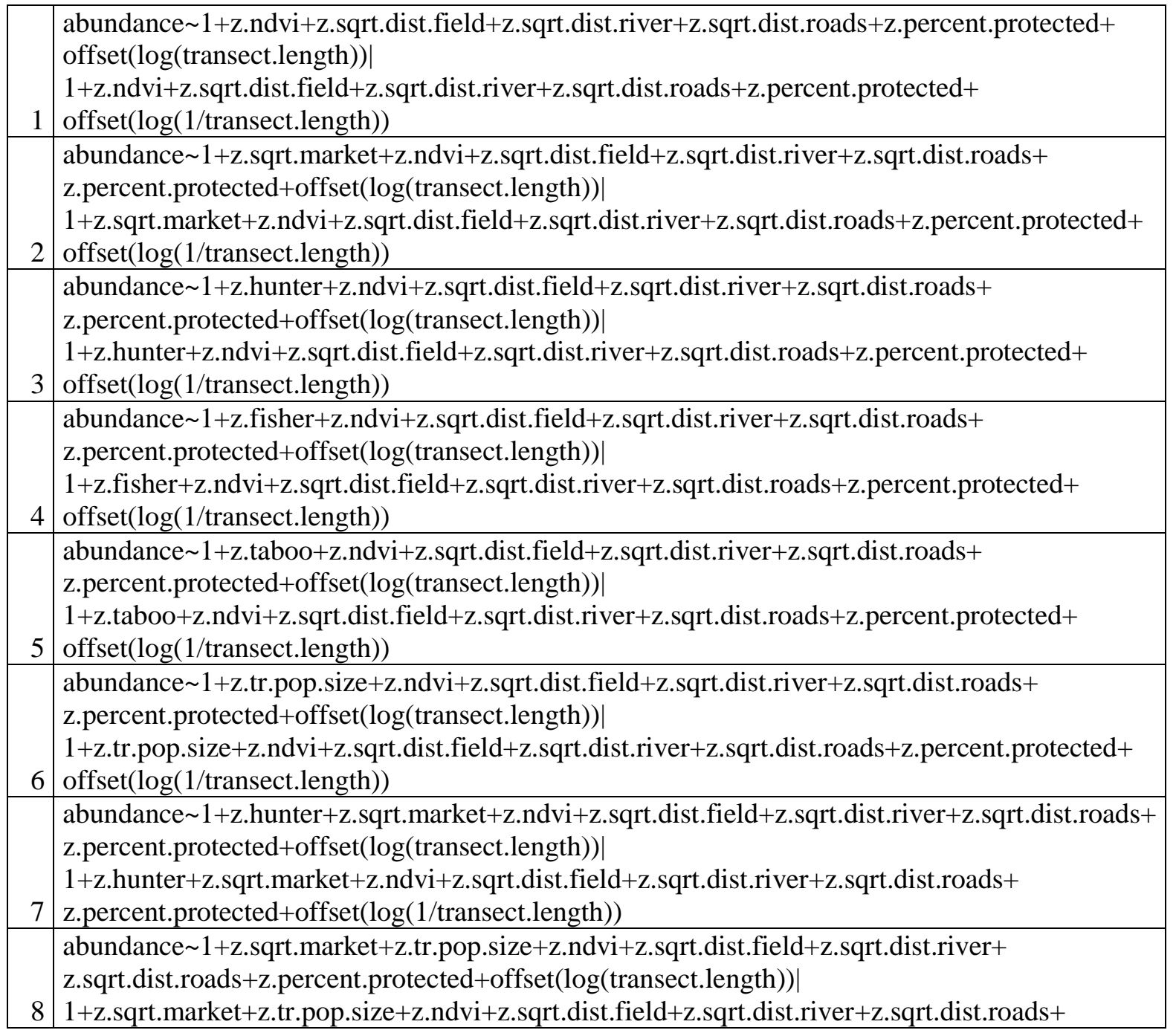




\begin{tabular}{|c|c|}
\hline & z.percent.protected+offset(log(1/transect.length $))$ \\
\hline 9 & abundance $1+$ offset $(\log ($ transect.length $)) \mid 1+$ offset $(\log (1 /$ transect.length $))$ \\
\hline 10 & $\begin{array}{l}\text { abundance } 1+\text { z.sqrt.market+offset }(\log (\text { transect.length })) \mid 1+\text { z.sqrt.market+ } \\
\text { offset }(\log (1 / \text { transect.length }))\end{array}$ \\
\hline 11 & abundance $1+$ z.hunter+offset $(\log ($ transect.length $)) \mid 1+$ z.hunter+offset $(\log (1 /$ transect.length $))$ \\
\hline 12 & abundance $1+$ z.fisher+offset(log(transect.length $)) \mid 1+$ z.fisher+offset $(\log (1 /$ transect.length $))$ \\
\hline 13 & abundance $1+$ z.taboo+offset(log(transect.length $)) \mid 1+$ z.taboo+offset(log $(1 /$ transect.length $))$ \\
\hline 14 & $\begin{array}{l}\text { abundance 1+z.tr.pop.size+offset(log(transect.length })) \mid 1+\text { z.tr.pop.size+ } \\
\text { offset(log(1/transect.length }))\end{array}$ \\
\hline 15 & $\begin{array}{l}\text { abundance } 1+\text { z.hunter+z.sqrt.market+offset }(\log (\text { transect.length })) \mid 1+\text { z.hunter+z.sqrt.market+ } \\
\text { offset }(\log (1 / \text { transect.length }))\end{array}$ \\
\hline 16 & $\begin{array}{l}\text { abundance 1+z.sqrt.market+z.tr.pop.size+offset }(\log (\text { transect.length })) \mid 1+z . s q r t . m a r k e t+ \\
\text { z.tr.pop.size+offset }(\log (1 / \text { transect.length }))\end{array}$ \\
\hline
\end{tabular}

